\title{
The First Amendment's Implied Political Establishment Clause
}

\author{
Robert D. Kamenshine $\dagger$
}

I

INTRODUCTION

The freedom-of-speech clause of the first amendment contains no express prohibition agamst political establishment-the advocacy of political viewpoimts by or with the assistance of government. ${ }^{1}$ That clause prohibits only government interference with the freedom of expression. In contrast, the first amendment's religious freedom provision explicitly forbids the government from restricting the free exercise of religion and from establishing religion. ${ }^{2}$

This Article proposes that the courts should read the first amendment to contain an implied prohibition against political establishment. It further argues that traditional analysis under the religious establishment clause is instructive of how courts should implement the political establishment prohibition. The premise of this new reading is that participation by the government in the dissemination of political ideas poses a threat to open public debate that is distinct from government impairment of individual expression. Programs of direct government dissemination and private dissemination that is government subsidized not only inform but also persuade. The government has the potential to use its unmatched arsenal of inedia resources and legislative prerogatives to obtain political ends, to nullify the effectiveness of criticism, and, thus, to undermine the principle of self-government. The free exercise of political rights, therefore, depends as much on a guarantee against political establishment as it does on the guarantee agamst interference with free speech.

Part I of this Article develops the theoretical basis for the political establishment prohibition. It deinonstrates that the implication of such a prohibition is necessary and, as the similar implication of the freedom

$\dagger$ Professor of Law, Vanderbilt University. B.A. 1961, College of the City of New York; J.D. 1964, Columbia Law School; LL.M. 1967, Harvard Law School. The author would like to express his appreciation to his student research assistant, Robert M. Bastress, Jr., now Assistant Professor of Law, University of West Virginia College of Law, for his invaluable aid in the preparation of this Article.

1. "Congress shall make no law ... abridging the freedoin of speech, or of the press . . ." U.S. Const. ainend. I.

2. "Congress shall nuake no law respecting an estabhishunent of religion, or prohibiting the free exercise thereof . . ." Id. 
of association illustrates, proper to fully effectuate the policies of the first amendment's freedom-of-speech guarantee.

Part II demonstrates that a political establishment prohibition is closely, if not perfectly, analogous in purpose to the religious establishment prohibition. It argues, therefore, that the analytic framework developed in religious establishment decisions is, with the exception of one element, appropriate for analyzing political establishment problems.

Part III applies the analytic framework developed in Part II to several examples of political establishment problems. This section considers two types of problems. The first is the dissemination of political views by the government to, for example, the general public, students in public educational institutions, and military personnel. The second type is government support for private advocacy. This is illustrated by government provision of public forums, financing for political campaigns, legal services for the poor, and favorable tax treatment.

\section{II}

\section{The Theoretical Basis for a Constitutional Prohibition of Political Establishment}

\section{A. The Interest to Be Protected}

A free marketplace of political ideas is essential to the proper functioning of a democratic system. Thus, the Supreine Court has stated that the purpose of the first amendment is to "preserve an uninhibited marketplace of ideas in whicl truth will ultnnately prevail, rather than to countenance inonopolization of that market, wliether it be by the Government itself or a private [broadcast] licensee. . . . '[S]peech concerning public affairs is more than self-expression; it is the essence of self-governinent." "3 If a government can mampulate that marketplace, it can ultimately subvert the processes by whicli the people hold it accountable. ${ }^{4}$ It is just such mampulation that the guarantee of a "system

3. Red Lion Broadcasting Co. v. FCC, 395 U.S. 367, 390 (1969). See also New York Times v. Sullivan, 376 U.S. 254, 269-70 (1964); A. Meiklejohn, Political Freedom: The Constitutional Powers of the People 24-28 (1965).

4. Professor Vincent Blasi has argued for explicit consideration in first amendment theory of a more limited "checking value," i.e, the role which this constitutional guarantee plays in curbing the abuse of official power. He suggests that this represents a more realistic view of the citizen's participation in self-government in that it does not envision a day-to-day involvement in public affairs, but rather a sporadic concern with grave abuses of power. Blasi, The Checking Value in First Amendment Theory, 1977 AM. B.F. RESEARCH J. 523, 561-62.

Whether one speaks of the broad value of self-government or the narrower "cliecking value," the concern with sueh government manipulation is equally great. In fact, the manipulation is most likely to occur in those instances of official "abuse of power" to which Professor Blasi refers. 
of freedom of expression"5 was intended to prevent.

Laws or programs that operate to restrict an individual's free expression are not the only threat to the system of freedom of speech. Government programs which disseminate information or assist private disseminators also pose a threat to that system.

Leading cominentators have recognized that this danger is potentially far-reaching. In the first major critical analysis of government participation in cominumication, Professor Chaffee concluded that

[t] here are some things which the private press cannot do, and so it has to be supplemented by government. The trouble is that there is nothing like the "clear and present danger" test to fix a stopping point. An ambitious official with enormous public funds at his disposal inight be tempted to drown out the private press. ${ }^{6}$

Several years later, Professors Emerson and Haber addressed the same problem:

The penetration of government into more and inore aspects of modern life, imcluding the field of mass commumication; the increasing dependence of higher education and scientific research upon governinent support; the inany forms of pressure toward political, intellectual and social conformity-these and other factors raise grave issues as to the proper role of government in controlling communication and inolding thought and expression im a democratic society. ${ }^{7}$

Political establishinent is clearly a subject of first amendment concern. It threatens the primary object that the freedom-of-speech clause was designed to protect; a free marketplace of ideas necessary to true self-government. Thus, the Court may appropriately interpret the first amendinent to protect agamst this threat.

\footnotetext{
5. Professor Emerson describes the "system of freedom of expression" as follows: This set of rights . . . includes the right to form and hold beliefs and opinions . . . and to communicate ... through any medium-in speech, writing, music, art, or in other ways. To some extent it involves the right to remaim silent. From the obverse side it includes the right to hear the views of others... It encompasses the right to inquire and, to a degree, the right of access to information. As a necessary corollary, it embraces the right to assemble and to form associations, that is, to combine with others in joint expression.
}

T. EMERSON, The SYSTEM OF Freedom of EXPRESSion 3 (1970).

6. 2 Z. Chafee, Government and Mass Communication 723, 796 (1947).

7. Emerson \& Haber, The Scopes Case in Modern Dress, 27 U. CHI. L. Rev. 522, 522

(1960). See also Van Alstyne, The First Amendment and the Suppression of Warmongering Propaganda in the United States: Comments and Footnotes, 31 L. \& CoNTEMP. Prob. 530 (1966). Van Alstyne comments:

With regard to formally-sponsored, government-generated propaganda directed to the nation at large, moreover, the first amendment may even be used to forbid it, rather than to protect it. Strange as it must sound in appraising an amendment which explicitly forbids abridging the freedom of speech, it is nonetheless arguable that the function of that amendmeut implicitly requires some silencing of the government itself.

Id. at 532 (emphasis in original). 


\section{B. The Need for a Separate Establishment Provision}

Government promulgation of political views presents dangers to the interests whicli the Framers intended the first amendment to protect. This alone, however, does not justify the proposed prohibition. It must also be sliown that the existing interpretation of the freedom-ofspeecli clause imadequately protects these imterests.

Historically, most challenges to political establishment have arisen in the context of indirect government aid to private dissemination. Courts have used the traditional free speecl interpretation to analyze these cases. Abood v. Detroit Board of Education, ${ }^{8}$ for example, involved a Michigan statute that authorized an agency shop agreement between teachers' unions and local boards of education. The agreeinent in this case required each employee, whether or not a union ineinber, to pay to the union a service fee equivalent to union dues. A group of teachers challenged the constitutionality of this agreement because it permitted the union to finance from these compulsory fees political activities whicli they found objectionable. The Supreme Court stated that the freedom to contribute to political activities also implied the right to refrain from contributing. ${ }^{9}$ It lield that the State could finance sucli political activities only from momies "paid by union employees who do not object to advancing those ideas and who are not coerced into doing so agamst their will by the threat of loss of government einployment." 10

The Court did not specify the exact form of relief to be awarded in Abood. ${ }^{11}$ It did state, however, that the remedy sliould eliminate the coinpelled exaction of that portion of the service fee devoted to political expenditures. ${ }^{12}$ Sucli a remedy would prevent the government froin compelling nonassenting employees to adhere to the union's political position. Moreover, this approach would solve the pohtical establishment problem by terminating the State's involvement in the union's political speech. The urion would remain free to continue its political activities by using voluntarily contributed funds, but it could not in-

\footnotetext{
8. 431 U.S. 209 (1977).

9. Id. at $235-36$.

10. Id.

11. Abood was before the Court after a judgment on the pleadings. The Court stated: The allegations in the complaint are general ones, ... and the parties have neither briefed nor argued the question of what specific umion activities . . properly fall under the definition of collective bargaining. . . . All that we decide is that the general allegations in the complaint, if proven, establish a cause of action under the First and Fourteenth Amendments.
}

Id. at 236.

12. Id. at 240 . 
voke the agency shop statute to collect funds for those activities. ${ }^{13}$

Abood apparently suggests, therefore, that the "compelled adherence" interpretation of the free speech guarantee, ${ }^{14}$ by preventing the government from using taxpayers' dollars for the dissemination of pohitical ideology, serves both the free exercise and pohtical establishment objectives of the first amendment.

Abood addressed, however, only one type of undesirable government participation in the marketplace of political ideas-an extremely indirect one at that. Government may provide more direct aid to private disseminators through, for example, subsidies from tax revenues. Or it may even engage in political speech of its own. The remedy suggested by $A b o o d$-the refund to objecting taxpayers of that portion of their taxcs designated for political purposes-would not only be extreinely burdensome to administer in these situations, but it would leave the government involved in the political debate. In the case of subsidies to private political advocates, the government would still provide the valuable function of gathering funds for the purpose of aiding disseminators of a particular viewpoint, even if those funds are only voluntary. In the case of direct government advocacy, the government would obviously still bring all of its prestige and economies of scale to bear on the political debate. Thus, in both situations, the dangers to first ainendment values inherent in government distortion of the mar-

\section{Id. at 235-36.}

In Smigel v. Southgate Community School Dist., 388 Mich. 531, 202 N.W.2d 305 (1972), the Michigan Supreme Court had held that while agency and union shop clauses were speeifically permitted for employees of private companies, the Public Employees Relations Act forbade such clauses in the public sector. The Michigan legislature responded by enacting an amcndment to the effect that "nothing in the [Public Employees Relations Act] or in any law of this state shall preclude [agency shop agreements]." Mich. CoMp. LAws §432.210(1)(c), Mich. STAT. ANN. $\S 17.455(10)$ (1970).

It may be persuasively argued that by "authorizing" agency shop agreements all the amendment did was to place the State in a position of neutrality vis-a-vis such agreements, neither forbidding nor requiring them. But see Reitman v. Mulkey, 387 U.S. 369 (1967); Burton.v. Wilmington Parking Auth., 365 U.S. 715 (1961).

14. This assumes that objecting employees would be given refunds based on all political expenditures. However, im Abood, as in previous labor union decisions, the Court sustained the exaction of contributions to cover a union's collective bargaining, contract administration, and grievance adjustment functions. 43I U.S. at 232. The teachers challenging the agency shop had contended that their case was distinguishable from Railway Employees' Dep't v. Hanson, 351 U.S. 225 (1956), and International Ass'n of Machinists v. Street, 367 U.S. 740 (1961), in that "dccisionmaking by a public employer [with respect to normal collective bargaining issues] is above all a political process." 431 U.S. at 228. The Court's reply was to concede the "truism" that such "attempt[s] to influence governmental policy-making . . . activities . . . may be properly termed pohtical" but to suggest that this "does not raise the ideas and beliefs of public employees onto a higher plane than the ideas and behefs of private employees." Id. at 23I. This ignores the point that as to collective bargaining issues, just as to other public policy issues, the contributions of objecting union members were being used to influence political decisionmaking by public officials. 
ketplace of ideas would remain. ${ }^{15}$

Furthermore, there nay be cases where government disseinination of political views will cause a serious estabhishment problem but not an unconstitutional impairment of individual expression. ${ }^{16}$ In such cases, a court obviously would not apply a remedy for coinpelled adherence. Thus, even if it were possible to fashion a coinpelled adherence reinedy that also always resolved political establishment problems, many such problems would remain unresolved where the restriction on free expression had not reached the level of a constitutional violation.

This denonstrates that the existing interpretation of the freedoinof-expression clause fails to afford adequate protection against governinent dissemination of political viewpoints. An independent pohitical establishment prohibition is clearly necessary.

\section{Implying a Clause in the First Amendment}

In his concurrence in Lathrop $v$. Donohue, ${ }^{17}$ Justice Harlan argued that the "distinction in the wording . . . between the protections of speech and religion" 18 precludes the imphication of a political establishinent prohibition in the first ainendment. This statement, however, is not conclusive. The Suprene Court has stated on many occasions that

15. The inadequacy of compelled adherence analysis to remedy this type of problem is highlighted by the difference between the religious establishment and free exercise clauses of the first amendment. This difference was well described in the school prayer decision, Engel v. Vitale, 370 U.S. 421 (1962). In that case, as in decisions dealing with financial aid to parochial schools, there was a sinall element of compulsion: people were forced to pay taxes, a miniscule portion of which was allocated to the support of religion. To this extent, a free exercise problem was created. The Court also recognized an element of coercion in that "[w]hen the power, prestige, and financial support of government is placed behind a particular religious behef, the indirect coercive pressure upon religious mimorities to conform to the prevailing officially approved rehigion is plain." Id. at 431. But the Court did not consider the free exercise aspect to be of primary importance. Instead, it emphasized the fact that the first amendinent prohibits any form of governmentally sponsored religious activity: "The Establishment Clause, unlike the Free Exercise Clause, does not depend upon any showing of direct governmental coinpulsion and is violated by the enactment of laws which establish an official religion whether those laws operate directly to coerce nonobserving individuals or not." Id. at 430 .

It would certainly be an inadequate response to a case such as Engel to recognize and redress only the impairment of the plaimtiff' free exercise rights. This would mean allowing the official school prayers to continue and unerely refunding to objecting taxpayers whatever portion of their taxes was paid for this program, thus leaving the government in the busimess of disseminating religion. Similarly, simply reheving taxpayers of the compulsion to pay for government dissemination of political views to which they object would not solve the greater problem of governmental manipulation of the inarketplace of ideas.

16. Under traditional free speech analysis, the government may justify curtailinent in some instances with countervailing legitimate state interests. Or a court may even consider the curtailment de minimus. See, e.g., Engel v. Vitale, 370 U.S. 421 (1962) (prayer sessions prohibited in public schools). See also text accompanying notes $42-44$ infra for discussion of balancing state interests against establishment effects.

17. 367 U.S. 820 (1961).

18. Id. at 852 . 
the freedom-of-speech clause protects more than direct individual expression; the clause imphicitly prohibits impairments of the freedom of association ${ }^{19}$ and laws or programs that compel adherence to government-prescribed views. ${ }^{20}$

By restricting political association or compelling adherence to political views, the government can subvert the system of democratic selfgovernment. The Supreme Court has read into the freedom-of-speech clause prohibitions on such government activities. Arguably, the implication of a pohtical estabhishment clause would serve the same purpose as those prohibitions: to minimize government distortion of the democratic process. ${ }^{21}$ These prohibitions thus provide persuasive precedent for a further expanded reading of the first amendment.

\section{The Scope of the Implied Prohibition}

\section{The Conceptual Limits}

Political expression is clearly at the core of first amendment concerns. The first amendment also protects, however, artistic, hiterary, philosophic, social, econormc, ${ }^{22}$ and even some purely commercial forms of expression. ${ }^{23}$ Furthermore, the Supreme Court has held that the implied first amendment rights, such as the freedoin of association, protect nonpolitical, as well as political, activities: there is a freedom to associate for other-than-political objectives. ${ }^{24}$

Such an expansive reading of the first amendinent may be inappropriate for an implied political estabhshment clause. Indeed, the elevation of the establishment aspect of freedom of speech to a position coextensive with the free exercise aspect would jeopardize many valu-

19. See, e.g., Healy v. James, 408 U.S. 169, 181 (1972); Gibson v. Florida Legislative Investigation Comm., 372 U.S. 539, 544 (1963); NAACP v. Alabama, 357 U.S. 449, 462 (1958).

20. See, e.g., Wooley v. Maynard, 430 U.S. 705 (1977); West Virginia State Bd. of Educ. v. Barnette, 319 U.S. 624 (I943).

21. One writer has suggested that freedom of association as developed by the Supreme Court "has been little more than a short-hand phrase used . . . to protect traditional first amendment rights of speech and petition as exercised by individuals in groups." Raggi, An Independent Right to Freedom of Association, 12 HARv. C.R.-C.L. L. REv. 1 (1976).

22. In Abood the Court observed:

It is no doubt true that a central purpose of the First Amendment "was to protect the free discussion of governmental affairs.' . . . But our cases have never suggestcd that expression about philosophical, social, artistic, economic, literary, or ethical matters- to take a nonexhaustive list of labels-is not entitled to full First Amendment protection.

431 U.S. at 231. Even "prurient, patently offensive depiction or deseription of sexual conduct" deserves first amendment protection if shown to have "scrious literary, artistic, political, or scientific value." Miller v. California, 413 U.S. 15, 26 (1973).

23. Virginia State Bd. of Pharmacy v. Virginia Citizens Consumer Council, lnc., 425 U.S. 748,762 (1976).

24. See Gilmore v. City of Montgoinery, 417 U.S. 556, 575 (1974); Moose Lodge v. lrvis, 407 U.S. 163, 179-80 (1972) (Douglas, J., dissenting). 
able and progressive government programs. The establishment prohibition would not only. prevent the government from favoring one political position over anotlier. It would also bar the government from supporting conteinporary art over traditional art, ballet over modern dance, and family-oriented entertainment over adult entertainment. Such a prohibition is absurd. The proposition that government is constitutionally prohibited from creating a museum of modern art or a children's theatre, or from providimg aid to similar private endeavors is difficult to take seriously.

Courts have recently considered the constitutionality of government imvolvement in nonpolitical expression, but only in the context of the effects of such involvement on freedom of expression. In Southeastern Promotions, Ltd. v. Conrad, ${ }^{25}$ the Supreme Court held that a decision by the directors of a municipal theatre not to schedule the musical "Hair" on grounds of obscemity was a prior restraint subject to usual first amendment due process safeguards. The majority opinion appears only to have extended the first amendment's protection of freedom of artistic expression. In his dissent, Justice Rehnquist argued that the decision went further. He expressed concern that it would effectively limit the ability of government organizations to support selected artistic endeavors:

[T]he apparent effect of the Court's decision is to tell the managers of municipal auditoriums that they may exercise no selective role whatsoever in deciding what performances may be booked. . . .

... May an opera house limit its productions to operas, or must it also show rock musicals? May a mumcipal theater devote an entire season to Shakespeare, or is it required to book any potential producer on a first come, first served basis? These questions are real ones in light of the Court's opinion, which by its terms seems to give no constitutionally permissible role in the way of selection to the municipal authoritics. ${ }^{26}$

Justice Rehnquist's fear that Southeastern Promotions endangers the government's ability to discriminate im its support of the arts has not materialized. In Advocates for Arts $v$. Thompson, ${ }^{27}$ for example, the First Circuit lield that the State of New Hantpshire had not violated the first amendnient by denymg an arts grant to a literary magazine which had published a poem that local officials considered to be offensive. ${ }^{28}$

25. 420 U.S. 546 (1975).

26. Id. at 571-73. Professor Karst deals with this problem by suggesting that such line drawing on the basis of content is permissible because the governmental interest served outweighs any speech interest. Karst, Public Enterprise and the Public Forum: A Commcnt on Southeastern Promotions, Ltd. v. Conrad, 37 OHIо ST. L.J. 247, 254, 259 (1976).

27. 532 F.2d 792 (1st Cir.), cert. denied, 429 U.S. 894 (1976).

28. Although Advocates reaches a proper result, the basis on which it distimguishes Southeastern Promotions is unsatisfying because it implicitly approves for "public places" the undesir- 
The First Circuit cane much closer in Advocates to recognizing the possibility of an establishment problem than did the Supreme Court in Southeastern Promotions. It stated that a direct attack on the constitutionality of public funding of the arts "would be undercut by the Supreine Court's interpretation of the first amendinent in Buckley v. Valeo,"29 that public financing of political campaigns would further rather than abridge first amendinent values. ${ }^{30}$ The court went on to discuss the inequality of support for different views that is the basis of tlie concern about establishment:

The real danger in the injection of government money into the marketplace of ideas is that the market will be distorted by the promotion of certain inessages but not others. To some extent, this danger is tolerable because counterbalanced by the hope that public funds will broaden the range of ideas expressed. . . . But if the danger of distortion were to be evidenced by a pattern of discrimmation impinging on the basic first amendment right to free and full debate on matters of public interest . . . a constitutional remedy surely would be appropriate. On where to draw the line, reasonable minds may differ. But in our view the refusal here to promote a magazine on the ground that it has published a poem ... which ... some may find offensive, falls short of the kind of discrimination that justifies judicial intervention in the name of the Constitution. ${ }^{31}$

able effects envisioned by Justice Rehnquist. First, the court stressed that in Southeastern Promotions the Supreme Court "chose to view the public auditorium 'as if it were the same as a city park or street . . . " 532 F.2d at 796 (quoting Southeastern Promotions, Ltd. v. Conrad, 420 U.S. 546, $570(1975))$. While there was "a tradition of freedom from government interference with expression in public places in our society," the court held that there was "no similar tradition of absolute neutrality in public subsidization of activities involving speech." Id. Second, it observed that "while it may be feasible to allocate space in an auditorium without consideration of the expressive content of competing applicants' productions, such neutrality in a program of public funding for the arts is inconceivable." $J d$. Finally, the court saw no realistic possibility of formulating constitutionally meaningful standards of artistic merit by which to circumscribe the discretion of the granting officials. Id. at 796-97.

Alternatively, the court could have distinguished Southeastern Promotions on either of two other grounds. First, because access to the auditorium was ostensibly available on a first-come, first-served basis, only an allegedly obscene play lawfully could not be booked. Thus, the denial of access to "Hair" imphicitly constituted a determmation that the play was obscene; that is, that its performance could result in crimmal liabihty. This naturally led the Court to apply the line of first amendinent decisions requiring strict procedural safeguards before such a prior restraint may be imposed. 420 U.S. at 558-62. See generally Karst, supra note 26, at 258-59. Second, Justice Douglas' dissent pointed out that "there was much testimony in the District Court concerning the pungent social and political commentary which the inusical 'Hair' levels against various sacred cows of our society: the Vietnam era, the draft, and the puritanical conventions of the Establishinent." 420 U.S. at 564 (Douglas, J., dissenting im part and concurring in part). To the extent that the political satire in "Hair" contributed to the directors' decision, a prior restraint on political speech was involved, as well as a government political establishment problem.

29. 532 F.2d at 795 .

30. Although the court's reliance on Buckley is arguably misplaced, see text accompanying notes 75-77 and 152-64 infra, this observation still serves to illustrate that government involvement in certain types of expression does not pose a threat to primary first amendment values.

31. 532 F.2d at 798. 
The First Circuit's suggestion that there are various degrees of government distortion of the marketplace of ideas-in effect, a contimuum of degrees-is helpful to establish the proper limits of an imphed establishment clause. The court correctly stated that no clearly defined point exists on the contmuum beyond which government imvolvement in the marketplace is clearly unacceptable. A general upper himit is apparent, however. The principal interest that the first amendment protects is freedom of political expression necessary to the proper functioning of a democratic system. In view of this, courts should deny a first amendment challenge to nonpolitical speech by the government. That is, because an implied prohibition on government speech stands as an assurance of the ultimate responsibility of the state to the electorate, and because, absent an underlying political aspect, ${ }^{32}$ government support for a particular artistic endeavor presents no danger of subverting democratic processes, the prohibition should exclude any concept of nonpolitical establishment.

\section{Applying the Limits}

The line between political and nonpolitical speech may be difficult to draw in some mstances, but this does not undercut its validity. ${ }^{33}$ Courts may simplify the task by borrowing a definitional framework from the Federal Communications Commission. To determine whether a broadcaster must present, under the "fairness doctrine," alternative views of an issue discussed on the air, the Commission has developed the concept of a "controversial issue of public importance;"33 a finding that the issue is both controversial and of public importance triggers the requirements of the fairness doctrine.

The first element of the Commission's standard-that the issue be "controversial"-necessitates measuring "the degree of attention paid

See also Toward a Gayer Bicentennial Comm. v. Rhode Island Bicentennial Found., 417 F. Supp. 632, 637 n.6 (D.R.I. 1976); Comment, Unconstitutional Government Speech, 15 SAN DiEGo L. REV. 815,834 (1978) (noting the risk that governmental speech may be inherently coercive and create an impression of governmental infallibility).

32. See Advocates for Arts v. Thomson, 532 F.2d 792, 798 (1st Cir. 1976); Toward a Gayer Bicentennial Comm. v. Rhode Island Bicentennial Found, 417 F. Supp. 632, 638-42 (D.R.I. 1976).

33. In Abood v. Detroit Bd. of Educ., 431 U.S. 209 (1977), the Court's decision necessitated a determination of which union activities were political in nature. The Court recognized that there would be "difficult problems in drawing lines between collective bargaining activities, for which contributions may be compelled, and ideological activities unrelated to collective bargaining." Id. at 236.

34. The Handling of Public Issues Under the Fairness Doctrime and the Public Interest Standards of the Communications Act-Fairness Report, 48 F.C.C.2d 1 (1974) [heremafter cited as Fairness Report]. 
to an issue by government officials, community leaders, and the media."35 For the most part, issues that relate to a social or political choice currently confrontimg a community come withm the scope of this definition. ${ }^{36}$

The Commission has described the second element of its test-that the issue be "of public importance"-as follows: "[t]he principal test of public importance . . . is not the extent of media or governmental attention, but rather a subjective evaluation of the impact that the issue is likely to have in the community at large."37

The question is whether courts should consider the "controversial issue of public importance" standard coextensive with the pohtical establishment concept. ${ }^{38}$ Clearly, any issue that falls imto the ambit of the fairness doctrine also would be subject to the prohibition agamst political establishment. The more difficult problem is whether the constitutional prohibition should exceed the scope of the fairness doctrineinore specifically, whether the Commission's requirement that the issue be "controversial" excludes from coverage some issues to which a pohtical establishment prohibition should apply.

An issue may have inajor public significance but not be controversial. The abstract debate over the relative merits of capitahism and socialisn is an example. This debate is clearly significant from a public policy perspective-it bears fundamentally on how a society should order itself. The capitahism-socialism debate, however, is hardly "controversial" in the United States-most Americans reject socialism as a viable social doctrine. Because of its lack of controversy, this issue would not satisfy the Commission's standard. Nevertheless, basic first anuendment values ${ }^{39}$ should require that courts prohibit government expressions of the intrinsic superiority of a capitalist society.

The fairness doctrine and pohitical establishment prohibition both

\section{Id. at 12 .}

36. Id.

37. Id.

38. The Federal Communications Commission has taken the position that the fairness doctrine's coverage is not coextensive with that of the freedom-of-expression guarantee. Fairness Report, 48 F.C.C.2d 1 (1974). In National Citizens Comm. for Broadcasting v. FCC, 567 F.2d 1095 (D.C. Cir. 1977), that element of the Fairness Report was upheld. In that case, the Commission's withdrawal of "standard product commercials" from the coverage of the doctrine was challenged as inconsistent with recent Supreme Court commercial speech decisions. Id. at 1105. The court heId that "[t] he persuasiveness-or lack thereof - of the commission's essential finding that standard commercials do not present 'a meaningful discussion of a controversial issue of public importance,' is not altered by the recent expansion of first amendment protection im the area of commercial speech." Id. at 1106 . The court reaehed this conclusion despite the fact that the Supreme Court's decision sustaining the constitutionality of the faimess doctrine, Red Lion Broadcasting Co. v. FCC, 395 U.S. 367 (1968), indicated that the doctrine itself was an attempt to implement first amendment values. $1 d$. at 390-91.

39. See text accompanying notes 3-7 supra. 
have their roots in the first anendment, but their specific purposes are soinewhat different. The purpose of the former is to ensure balanced coverage of public issues by the media. The broadcast media's monopoly over the procurement and dissemination of information, gamed by government licensing and scarcity of spectrum space, ${ }^{40}$ allegedly created this need. The purpose of the latter is to ensure the interchange of political ideas free of any distortion by government expression or selective subsidy. This goal apphes regardless of whether a particular viewpoint has achieved any degree of support even remotely approaching that necessary to make it "controversial" for purposes of the fairness doctrine ${ }^{41}$ Efforts to indoctrimate the public in or to perpetuate an accepted "conventional wisdom" are directly contrary to this objective. Consequently, only the "public importance" aspect of the Commission's test is relevant to whether government expression or support for private expression constitutes a pohtical estabhshınent. Obviously, such a test would give the constitutional prohibition a broader impact than that of the fairness doctrine standard.

\section{E. The Test of Constitutionality}

Once a government activity evidences a political establishınent problem, the question becomes what test a court should use to determine the constitutionahity of that activity. Three alternatives are apparent. First, courts could treat the existence of an establishinent as a per se violation of the Constitution. Second, they could subject the government activity to a strict scrutiny standard, striking down the activity unless there is a compelling countervailing interest. Third, they could balance the competimg interest without any special presumption. In view of the Supreme Court's treatment of the rehgious establishment prohibition, ${ }^{42}$ a strict scrutiny standard is appropriate.

40. Red Lion Broadcasting Co. v. FCC, 395 U.S. 367, 388-90 (1969).

Thus, in the context of the scarcity of broadcast frequencies and the resulting necessity for government licensing, the First Amendment impels, rather than prohibits, governmental promotion of a systein which will ensure that the pubhic will be mformed of the important issues which confront it and of the competing viewpoints on those issues which may differ from the views held by a particular licensee.

Fairness Report, 48 F.C.C.2d at 5-6.

41. Consider the speech found constitutionally protected in Brandenburg v. Ohio, 395 U.S. 444 (1969): "I believe the nigger should be returned to Africa, the Jew returned to Israel." Id. at 447.

42. Chief Judge Bazelon of the District of Columbia Circuit has stated that once an activity is found to be an establishment of religion it is per se illegal. Anderson v. Laird, 466 F.2d 283, 290 (1972). See also Zorach v. Clauson, 343 U.S. 306, 312 (1951). He interpreted Abington School Dist. v. Schempp, 374 U.S. 203 (1963), and Engel v. Vitale, 370 U.S. 421 (1962), to establish that secular interests may never justify government imposition of cliurch attendance. Anderson was decided by a three judge panel that held that compulsory cliapel attendance in United States inilitary academies was unconstitutional as an estabhishment of rehgion. Judge Leventhal, in a concurrence, found it uunecessary to reach the question whether establishments of religion were 
Under the strict scrutiny approach courts must balance the interests at stake. On one side is the interest in preventing political estabhishment. The overriding objective, of course, is to maintain an open marketplace of political ideas free from government distortion. On the other side are the interests that the government activity seeks to vindicate. The government would surely advance numerous pohcy considerations to support its activity. Giving added weight to the prohibition against pohtical establishments, the court must then weigh the competing interests to determine the validity of the government activity.

As a general proposition, courts would rarely uphold a governinent activity that establislies a political position. The strict scrutiny standard virtually guarantees that the interest in prohibiting political establishment will outweigh any countervailing interest in retaiming the activity.

In special circumstances, however, the government might successfully deinonstrate that the countervailing interest im continuing the government activity is compelling and, therefore, outweighs the interest im prohibitimg political estabhshinents. The most obvious is when enforcement of the prohibition would impinge on individual rights of free expression-rights that are as essential to the open marketplace of ideas as is the prohibition against establishment. When enforcement of the pohtical establishment prohibition would curtail these rights, the balance inay conceivably tip in favor of not enforcing the prohibition.

Soine may argue that the government has a compelling interest in stimulating support for its programs. The argument is that im order to operate effectively, the government must be able to advocate the merits of its pohicies and programs. Institutional dissemmation of this sort, however, conflicts with the goal of an open marketplace of ideas; it distorts public debate and thus raises serious estabhishment concerns. Its proponents claim, nevertheless, that this government interest outweighs the interest behind the political estabhshınent clause.

The response to this argument attacks not the balancing, but the asserted interest itself. Simply put, no such government interest exists. Admittedly, it is appropriate and necessary for someone to act as an advocate for existing policies. The government as an institution, however, is not the appropriate agent. Neither the Presidency nor Congress nor any other government office as an institution has an interest in promoting particular policies to the exclusion of others. Rather, it is the individuals occupying such offices who possess that interest. Thus, for

per se illegal. In a concurring opinion, he found that the chapel attendance requirement did not serve a coinpelling state interest. 466 F.2d at 310-14 (Leventhal, J., coneurring). Judge McKinnon dissented. 
example, it is the President in his individual capacity, and not the Presidency, who cares about the success or failure of a government program.

An obvious difficulty with this response is that courts must atteinpt to distinguish between mdividual and mstitutional speech. Two guidelines may be helpful. First, courts should examine the extent to which the speaker exphicitly portrays the capacity in which he is speaking. ${ }^{43}$ Second, they inust consider the extent to which government resources are used in the communication. For example, reports funded by a state public utility commission that advocate the developinent of nuclear energy and that appear on agency stationery are clearly institutional communications. On the other hand, pamphlets that explam the pronuclear position of an incumbent governor who is running for reelection and who finances thein with privately raised funds are clearly individual speech.

Not all cases, however, will be as clear-cut as these examples. The line between individual and institutional speech may at times be very obscure. In these situations, courts may have to balance the individual's interest in free expression agamst the interest in preventing pohtical establishments in order to define whether the speech is individual or institutional. This balance of interests, of course, is the same as the test of an estabhshment's constitutionality. Courts would use it at the defimitional stage only because of the difficulty of distinguishing the two types of speech. There is precedent for this practice in the rehious establishment context. For example, in O'Hair v. Paine, ${ }^{44}$ the court denied an injunction which would have prohibited NASA froin directing or permitting astronauts to broadcast prayers and bible readings froin space. It found that "[t]1he rehious stateinents of the astronauts while on television were made by the astronauts as individuals and not as representatives of the United States government." 45 The court's decision that the prayers were private acts and, thus, not subject to the establishment clause obviousiy represents a conclusion that the astronauts' free exercise rights outweighed any establishment concerns. ${ }^{46}$

43. Cf. Illinois Citizens' Comm. for Broadcasting v. FCC, 515 F.2d 397, 420 (D.C. Cir. 1975) (statements by FCC Chairman made in individual capacity). But see Writer's Guild of America, West, Inc. v. FCC, 423 F. Supp. 1064 (C.D. Cal. 1976), in which statements by the FCC Cliairman ostensibly in his individual capacity were found to be official. He impliedly threatened private broadcast organizations with stricter enforcement of regulations if the organizations did not adopt the "family viewing hour." These comments were considered official and made the network's response, i.e., adoption of the family lour, state action. Id. at 1140-43.

44. 312 F. Supp. 434 (W.D. Tex. 1969).

45. Id. at 437.

46. It may be argued that recent public einployee dismissal cases provide a constitutional basis for soine centralized control of the public's information regarding controversial government policies, and that this control would not be protected from establishment attack by the protection of individual free speech. In Pickering v. Board of Educ., 391 U.S. 563 (1968), and in Arnett v. 
These narrow considerations aside, it is apparent that most politi-

Kennedy, 416 U.S. 134 (1974), the Supreme Court purported to protect government employees from being discharged for engaging in constitutionally protected speeeh, but in both cases it recog* nized a legitimate governmental interest in protecting the reputation of an agency or program from employee criticism.

Although a teacher's dismissal was overturned in Pickering, the Court stated that an employee may be dismissed for criticism-even truthful criticism-of superiors when there is a need to preserve confidentiality or when the relationship between subordinate and superior is "of such a personal or intimate nature" that the effectiveness of the working relationship might be seriously undermined. 391 U.S. at 570 n.3.

In Arnett, the Court found that the dismissal of an OEO employee was justified, stating that "[t]he act [which authorizes dismissal for 'such causes as will promote the efficiency of the service'] proscribes only that public speech which improperly damages and impairs the reputation and efficiency of the employing agency, and it thus imposes no greater controls on the behavior of federal employees than are necessary for the protection of the Government as an employer." 416 U.S. at 162 (einphasis supplied).

Then, in Elrod v. Burns, 427 U.S. 347 (1976), the Court held that the first amendment protected all but policymaking employees from dismissal for political purposes. This distinction was based in part on the belief that the political loyalty of policymaking employees was needed to assure "that representative government not be undercut by tactics obstructing the implementation of policies of the new administration, policies presumably sanetioned by the electorate." $I d$. at 367. See also id. at 375 (Stewart, J., concurring).

Therefore, the argument goes, the Court's language combined with the fact that the frce speech rights of the dismissed employees were allowed to be curtailed indicates that the "individual rights" analysis has been disapproved by the Supreme Court-that the individual rights of the public officials lave been subordinated to the institutional interests of the agencies concerned in speaking with a "single voice."

There are three fundamental fiaws in this argument. First, in none of these three cases wcre the Court's comments on the validity of an agency's interest in stilling dissension in its ranks, and hence in controlling the information to whiels the public has access, essential elcments of the holdings. In Pickering, the Court held that because the employee's public communication related only tangentially to his job, he could be discharged only for "false statements knowingly or rccklessly made." 391 U.S. at 574. The Court's statement that "it cannot be gainsaid that the State has interests as an employer in regulating the speech of its employees that differ significantly from those it possesses in conneetion with the regulation of the citizenry in general," id. at 568, is related to the final decision only by negative implication. In Arnett, the dismissed employee was not charged with attacking his agency, but with accusing his supervisor of bribery. 416 U.S. at 137. In Elrod, agam, the need to permit agencies to protect their reputations and to command loyalty was but a concession made by the Court before it denied the agency's ability to discharge nonpolicymaking employees. 427 U.S. at 367 . It is conceivable, therefore, that the Court's endorsement of that mterest would be considered mere dictum if a substantial commitment of governmental resources to political advocacy were challenged.

Second, it overstates the violence done the first amendment rights of the employees discharged. Although the cases do indicate that employees may be discharged for what would, under otlier circumstances, be protected speecl, employees will retain the right to engage in that speeeh from outside the agency. In more cynical terms, no one las a first amendiment right to be paid for sabotaging his or lier employer's operation. Indeed, it may be argued that the right to vote for public officials would be impaired if the officials were not permitted to discharge subordinates who publicly spoke out against their policies. Thus, to couch the dismissal in only free expression teruns is to distort the character of the action taken.

Finally, and inost importantly, an argument that infers the Court's recognition of an institutional interest in government political speech fails to distinguish the steps sanctioned in Pickering, Arnett, and Elrod to protect against sabotage of policy from within programs designed to communicate affirmatively with the public. The latter is all that the suggested politieal establishment clause is intended to and would in fact prohibit. 
cal establishment cases will be won or lost at the point of identifying whether the government activity establishes a political position. Once a court has identified the existence of an establishment, it will almost certainly strike down the activity because of the strict scrutiny standard. It is therefore critical to develop a sound analytic framework for identifying political establishments.

\section{III}

\section{ANALOGY to Establishment of Religion}

The relationship between the guarantee of freedoin of expression and the proposed prohibition of political establishment is closely analogous to that between the religious free exercise and religious establishment clauses. The prohibition of religious establishments protects free exercise interests from a specific, particularly insidious threat: the coercive effects of a state rehigion. Similarly, the political establishment clause suggested here would protect the free speech values on which a deinocratic system depends froin the specific threat posed by government propagandizing. The analogy is not perfect, however. Political advocacy by the government is different from government involvement with religion. This difference affects the applicability of religious establishment's analytic frainework to political establishment problems. Therefore, before discussing the particulars of that franework, this section will examine and resolve the fundamental differences between the two types of establishment.

\section{A. Imperfections in the Analogy}

The government's interaction with religious organizations is fundainentally different from its interaction with political process. A democratic form of government can operate without controlling or being controlled by rehgious groups. The same is not true, however, with politics. The political process inust control the government if a democratic system is to survive.

This "imperfection" in the analogy between religion and political activity, however, does not undercut the validity of implying a political establishment prohibition in the first amendment. Indeed, it actually strengthens the argument for such a prohibition. The fact that the political process is the primary source of control over government inakes it all the more important that courts prevent the government froin manipulating that process. 


\section{B. The Relevance of the Establishment-of-Religion Analytic Framework to Political Establishment}

In Lemon v. Kurtzman, ${ }^{47}$ the United States Supreme Court succinctly stated the standards historically applied to identify an establishinent of religion. An establishment exists under Lemon if the challenged laws or programs: (1) have a sectarian purpose; (2) have as their primary effect the advancement or inhibition of religion; or (3) foster excessive government entanglement with religion. ${ }^{48}$ Because the analogy between religious and political establishments is imperfect, the standards for detecting religious establishments are not exactly suited to political establishment problems. Nonetheless, they provide valuable guidance in the application of an implied political establishment prohibition.

\section{Sectarian Purpose}

The sectarian purpose test has not been a significant factor in striking down legislation on religious establishment grounds. In almost no cases in which courts have apphed this test have they found a sectarian purpose. ${ }^{49}$

This does not necessarily inean that the analogous test for a "political purpose" will be equally insignificant in political establishment cases. It is conceivable that government action aimed at advancing a particular political viewpoint is nore common than similar action aimed at prounoting or inhibiting rehgion. ${ }^{50}$

\section{Primary Effect}

Unlike sectarian purpose, the primary effect test has been a major factor in the Supreine Court's resolution of establishment-of-religion probleins. The cases that apply this test are separable into two catego-

47. 403 U.S. 602 (1971).

48. However, the recent decision in Wolman v. Walter, 433 U.S. 602 (1971), raises some doubts as to the support that the religious entangleinent test commands on the Court. See Comment, Wolman v. Walter and the Continuing Debate over State Aid to Parochial Schools, 63 lows L. REv. 543, 552-53 (1977). Notwithstanding these doubts, the tripartite test remains the law and is useful as a framework for political estabiishment.

49. See Kosydar v. Wolman, 353 F. Supp. 744, 752 n.4 (S.D. Ohio 1972). In Epperson v. Arkansas, 393 U.S. 97 (1968) (invalidating a law prohibiting the teaching of evolution), the Court did find an impermissible sectarian purpose. Id. at 107-08. Previously, in McGowan v. Maryland, 366 U.S. 420 (1961), the Court determmed that while Sunday closing laws originally had a sectarian purpose, that was no longer true. Id. at 444-45.

50. This may be due in part to the much more direct incentive to undertake such activities; elected officials have a more personal stake in promoting their political views. Further, political establishment problems are inore likely to arise out of admmistrative activities than legislative enactments, and it may be easier to discern the "purpose" of the former type of activities than of the latter. 
ries that correspond to the two types of political establishment. ${ }^{51}$ The first category involves the intrnsion of religious matters into governinent programs, and is analogous to direct government dissemination of political views. The cases in this group primarily relate to school prayer $^{52}$ and bible reading. ${ }^{53}$ The second category involves governinent aid to private religious dissemination, and is directly analogous to assistance to private political dissemination. Most of the cases in this group concern government aid to parochial education. ${ }^{54}$

\section{a. Religion in Government Programs}

In this category of cases courts have discerned the primary effect of the questioned activity by assessing its religious character. For example, courts have held that school prayers and bible readings are so blatantly religious in nature that their primary effect is clearly the advanceinent of religion. ${ }^{55}$ By contrast, the Supreme Court has sustained Sunday closing laws on the ground that they establish no inore than a uniform day of rest and, consequently, are sectarian in neither purpose nor primary effect. ${ }^{56}$

A comparable primary effect analysis in cases of government political dissemination would focus on the partisan characteristics of the challenged cominunication. If such a dissemination presents only one side of a public issue, or otherwise appears to advocate a position rather than simply to report on government activity, courts would find that its primary effect is political indoctrimation.

\section{b. Government Aid to Religious Programs}

In cases of government aid to rehgious programs the determinative factor appears to be the character of the institutions receiving the aid rather than the nature of the programs themselves. Programs of aid to institutions that perform valuable secular functions have nevertheless failed under the primary effect test where the imstitution's principal purpose was the propagation of rehgious doctrime. For example, courts have prohibited almost all forms of aid to parochial schools because of the religious purpose of those schools. ${ }^{57}$

51. See text accompanying notes 14-15 supra.

52. E.g., Engel v. Vitale, 370 U.S. 421 (1962).

53. E.g., Abington School Dist. v. Scheinpp, 374 U.S. 203 (1963).

54. See, e.g., Committee for Pub. Educ. v. Nyquist, 413 U.S. 756 (1973).

55. Abimgton School Dist. v. Schempp, 374 U.S. at 223-24, 278-81.

56. McGowan v. Maryland, 366 U.S. 420 (1961).

57. The leading exceptions to this rule are Everson v. Board of Educ., 330 U.S. 1 (1947), and Board of Educ. v. Allen, 392 U.S. 236 (1968), in which the Court did permit a subsidy in the form of free bus transportation and loans of secular textbooks to parochial and public school students respectively. Three factors provided the rationale for these decisions: (1) the form of aid involved 
This analysis is equally appropriate in cases of government support for private political dissemination. Courts should examine whether the government prograin has a primary effect of advancing a political viewpoint. To accoinplish this, they inust focus principally on the recipient's purposes and its methods of operation, rather than the form of the particular assistance.

\section{Excessive Government Entanglement}

Like the primary effect test, the prohibition against "excessive government entangleinent" with religion lias been important in establishinent decisions. ${ }^{58}$ The objective of prohibiting excessive entanglement is "to prevent, as far as possible, the intrusion of either [the state or religious institutions] into the precincts of the other." 59 There are thus two forms of entanglennent. The first is "government intrusion." It consists of government supervision of religious activities-the intrusion of government into religion. ${ }^{60}$ The second is "religious intrusion." It concerns the efforts of organized religions to influence political debate-the intrusion of religion into the political process. ${ }^{61}$

Government intrusion problems only occur in cases of government aid to religious institutions. Ironically, they result froin efforts to shape aid prograins to avoid a finding that the primary effect of such prograins is the advancement of rehigion. For example, Lemon involved prograins that suppleniented the salaries of teachers of secular subjects in private eleinentary and secondary schools. ${ }^{62}$ The plans under attack contained safeguards to prevent teachers from injecting religious eleneents into their classes. Striking down the programs, the Court held

was inherently neutral with respect to religious doctrine; (2) under the so-called child benefit theory, the aid was directed to the student rather than to the school; and (3) the aid programs at issue were available to children in public as well as private schools.

Beyond Everson and Allen, howcver, the Court has generally been persuaded that channeling funds or inaterials dircctly to parochial schools involves an unacceptable risk that such aid will support the institutions' religious purposes. See Meek v. Pittenger, 421 U.S. 349, 366 (1975); Committee for Pub. Educ. v. Nyquist, 413 U.S. 756, 767-68 (1973); Lemon v. Kurtzman, 403 U.S. 602, 615-16 (1971). Where the aid was ostensibly directed to the parents rather than to the school, the Court dcclined to follow the child benefit rationale described above, stating that it was only one factor in assessing primary effect. See Committee for Pub. Educ. v. Nyquist, 413 U.S. 756 (1973). In the case of tuition reimbursement and incoine tax rehief, the Court found such effect because the programs encouraged and rewarded the parent for sending his or her children to schools having religious indoctrination as a principal purpose. Id. at 786, 791. This conclusion did not depend on any deinonstration that the parent was serving as a mere conduit for directing public inoney to the private institution.

58. See, e.g., Meek v. Pittenger, 421 U.S. 349, 372 (1975); Committee for Pub. Educ. v. Nyquist, 413 U.S. 756, 794-98 (1973); Leinon v. Kurtzman, 403 U.S. 602, 615-24 (1971).

59. 403 U.S. at 614.

60. Id. at $615,619-20,622$.

61. Id. at 622-24.

62. Id. at 607-10. 
that the cumulative impact of these safeguards was excessive government involvement in the affairs of sectarian schools. ${ }^{63}$ The Court admitted that some contacts between government and rehion are "necessary and permissible" (for example, fire imspections, building and zoning regulations, and state requirements under compulsory school attendance laws) ${ }^{64}$ It insisted, however, that the contacts contemplated by the plans in Lemon were impermissible because they required government supervision of the instruction itself. ${ }^{65}$ The plans, in effect, asked the recipients of aid to curtail their first amendment right of free exercise as a condition of obtaining government money. ${ }^{66}$

The Court also addressed in Lemon the problem of religious intrusion into political matters. It envisioned a bitter amual struggle over appropriations for the programs at issue, ${ }^{67}$ and observed that "[o]rdinarily pohtical debate and division . . . are normal and healthy manifestations of our democratic system of government, but political division along religious lines was one of the principal evils agamst which the First Amendment was intended to protect." 68 Thus, political division over religion "could divert attention from the myriad issues and problems that confront every level of government." 69

The difference between government's relations to religion and to politics limits the applicability of the entanglement aspect of the Lemon test to political establishment in two respects. First, the political establishment analogue to "religious intrusion" analysis is mapplicable alnost by definition. Religious intrusion concerns the intrusion of organized religion into the political process. By definition, however, political groups are a part of the political process. Therefore, it is ludicrous to develop an entanglement test that measures the extent of political intrusion into the affairs of government.

Second, the political establishment analogue to "government $\mathrm{m}$ -

63. Id. at 607 .

64. Id. at 614 .

65. Id. at 618-19, 620-22.

66. Justice Brennan's partial concurrence in Lemon did address this problem. Id. at 649-52 (Brennan, J., concurring in part). Cf. Sherbert v. Verner, 374 U.S. 398 (1963) (violation of free exercise to deny unemployment benefits because of religiously based refusal to work on Saturdays). But see Johnson v. Robison, 415 U.S. 361 (1974) (upholding denial of veterans' educational benefits to alternative service conscientious objectors).

67. 403 U.S. at 623.

68. Id. at 622 . Consistent with estabhshment clause analysis, the Court did not consider whether the required governmental supervision might be deemed an unconstitutional condition on the right of free exercise, although Justice Brennan did address this problem in his concurring opinion. See note 66 supra. The Court assumed that it was inherently bad for government to engage in supervision so intimately connected with free exercise and that coercion or penalization of the aid recipients was irrelevant. 403 U.S. at 619. See also Committee for Pub. Educ. v. Nyquist, 413 U.S. at $786-87$.

69. 403 U.S. at 623. 
trusion" analysis is applicable to only one of the two types of political establishment problems. Government intrusion in the religious context consists of government interference with the management of religious institutions. In a political context, however, this test of entanglement would focus on the extent of government intrusion into the affairs of government, a patent absurdity. Therefore, this analysis does not apply to direct government dissemination. It is appropriate only in cases of government aid to private political communication, where considerations of government interference are clearly relevant.

Thus, the application of entanglement analysis to political establishment questions is as follows. The government may not provide aid to private organizations in a way that will have political establishment effects. Government-imposed precautions against such effects may intrude into inanageinent of those organizations and threaten to curtail their freedoin to engage in political activities. At some point that intrusion becoines so great that it violates the first amendment guarantee of free speech. Therefore, courts should use the political establishment clause to prohibit government aid that necessitates such a level of intrusion.

\section{Precedential Obstacles}

In Wooley v. Maynard, ${ }^{70}$ the Supreme Court held that the first antendnent prohibited New Hampshire from enforcing criminal sanctions against persons who covered the motto "Live Free or Die" on their autontobile license plates because of ideological opposition. The Court reasoned that covering the license plates was an exercise of the right to refrain from speaking:

The State's . . interest is not ideologically neutral. The State is seeking to coinmumicate to others an official view . . . . Of course, the State inay legitimately pursue such interests. However, where the State's imterest is to disseminate an ideology, no matter how acceptable to some, such interest caimot outweigh an individual's right to avoid becoming the courier for such message. ${ }^{71}$

The striking aspect of this statement is not the Court's recognition of the automobile owner's right of free expression, but its acceptance of the legitimacy of government dissemination of an ideology. ${ }^{72}$ Yet it refiects the usual conception of the freedoin-of-speech guarantee as only a limitation on govennent interference with the right of individuals to free expression.

While the language in Wooley approving government propagation

70. 430 U.S. 705 (1977).

71. Id. at 717 .

72. But see Comment, supra note 31 , at 838 (arguing that in Wooley there was an "implied recognition of the unconstitutionality of government speech"). 
of political ideology is merely dictum, courts have expressed more direct disapproval of the political establishment concept; on more than one occasion, they have rejected challenges to government programs based on analogies to religious establishment. The most troublesome such cases are Buckley $v$. Valeo ${ }^{73}$ and Joyner v. Whiting. ${ }^{74}$

In Buckley, petitioners challenged the national program for public campaign financing on first amendment grounds, raising an analogy to religious establishment. The Supreme Court rejected this challenge.

The Court's analysis in Buckley, however, clearly reseinbled the way in which courts would proceed under a political establishment framework. First, the Court clearly found that there was no "political" purpose; the government intended the program to enlarge public discussion rather than to promote any particular pohitical position. ${ }^{75} \mathrm{Sec}-$ ond, it found that the program did not invidiously discriminate among proponents of competing political views. ${ }^{76}$ This amounts to a finding that there was no primary effect of promoting one pohtical position over another. Fimally, the Court stated that the reporting requirements imposed on the recipients of federal financing did not unreasonably impinge on the free expression rights of those recipients. ${ }^{77}$ There was, in other words, no excessive entanglement. Viewed in this manner, Buckley seems to be a case that applied rather than rejected political establishment analysis. ${ }^{78}$

In Joyner $v$. Whiting, an official of a state-supported college withdrew funding from a student newspaper that pursued a segregationist editorial policy, contending that state funding of such editorials would constitute an unconstitutional establishment of a political position. The Fourth Circuit explicitly rejected the official's analogy to the rehgious establishment clause and supported the right of the government to disseminate a political view. ${ }^{79}$

73. 424 U.S. 1 (1976).

74. 477 F.2d 456 (4th Cir. 1973).

75. 424 U.S. at $92-93$.

76. Id. at 93-96. This finding is criticized in the text accompanying notes 157-64 infra.

77. Id. at 93 n. 126.

78. The Buckley Court, in a footnote, distinguished the historical bases of the rehigious and free speech clauses of the first amendment. It stated that the former arose from a fear of government persecution whereas the latter was intended to ensure the robust debate on public issues necessary to a healthy democracy. $I d$. at $92-93$ n.127. This distinction, however, supports rather than refutes the implication of a political establishment clause; such a clause is at least as necessary to ensuring truly free debate as a rehgious estabhshment clause is to preventing persecution.

79. 477 F.2d at 461 . The court stated:

The court's rationale disregards the distinction between the First Amendment's clause prohibiting the establishment of religion and its clause protecting freedom of the press. Neither federal nor state governments may expend funds to establish a religion. The First Amendment, however, contains no similar ban against speech or press. Both governments may spend money to publish the positions they take on controversial subjects. 
This outcome is not inconsistent with political establishment analysis. First, editorializing in a school newspaper does not, in most circumstances, constitute government establishment of a political position. ${ }^{80}$ When the editors enjoy only a relatively short tenure, there is sufficient opportunity for proponents of opposing views to control the paper tliat tliere is no primary effect of state support for a particular position.

Second, Joyner was a free press case; the student editors had contended that the cessation of funding abridged their right of free expression. Consistent witl political establishment analysis, the Court balanced the editors' interest in free speech agamst the alleged interest in preventing state establishment of a political position and found that the school had successfully rebutted the presumption of unconstitutionality.

Tlius, these two most difficult cases are, in fact, consistent with political establishment analysis. The ostensibly hostile dicta in Wooley and other cases, therefore, sliould not bind courts in pohtical establishinent cases.

IV

Application of Political Establishment Principles

\section{A. Government Advocacy}

\section{Dissemination to the General Public}

Most commentators associate domestic propaganda with dictatorial governments; the dictatorship uses a centralized agency to mold public opinion througlı a monopoly on communication. ${ }^{81}$ This coun-

The speeches and publicatious that originate in government offices attest to the diversity of views that are freely expounded.

Id. at 461 (emphasis added). See also Arrington v. Taylor, 380 F. Supp. 1348 (M.D.N.C. 1974), affd without opinion, 526 F.2d 587 (4th Cir. 1975). But see Mountain States Legal Found. v. Denver School Dist., 459 F. Supp. 357, 360-61 (D. Colo. 1978) (school board's expenditure of public funds to defeat a proposed constitutional amendinent "violates a basic precept of this nation's deunocratic processes").

80. See text accompanying notes $140-43$ infra.

81. In a definition revealing for political establishment purposes, propaganda was defined as the use of facts, fiction, argument and suggestion, sometimes supported by an effort to suppress inconsistent material, with the calculated purpose of instilling in the recipient certaim beliefs, prejudices, or convictions which will serve the interest of the author, usually by producing or tending to produce a certain line of action.

J. Whitton \& A. Larson, Propaganda Towards Disarmament in the War of Words 9 (1964) (empliasis added). Another commentator defined it as:

'a techmique of social control,' which manipulates collective attitudes by the use of significant symbols (words, pictures, tunes) ... . Propaganda differs froin the technique of pedagogy in that propaganda is concerned with attitudes of love and hate while 
try, except in wartime, ${ }^{82}$ has never had an official domestic propaganda department or a special office of information. ${ }^{83}$ Certainly a meaningful prohibition against political establishment would bar the creation of such a permanent government agency.

$$
\text { In Wooley v. Maynard, the Supreme Court permitted New Hamp- }
$$

pedagogy is devoted to the transmission of skill. The use of significant symbols to inculcate love of family, country, God, democracy, and constitution is propaganda; the use of significant symbols to develop skill in mathematics, logic, chemistry, or reading is pedagogy.

Lasswell, The Person: Subject and Object of Propaganda, 179 ANNals 187, 189 (1935). See generally Z. ChAFEe, supra note 6, at 763-68; G. ORwell, 1984 (1949); Fainsod, Review of McCamy, Government Publicity-Its Practice in Federal Administration (1939), 53 HARv. L. REv. 522, 523 (1940); Marx, Propaganda and Dictatorship, 179 ANNals 211 (1935). See also Siegel, Radio and Propaganda, 10 AIR L. Rev. 127, 127-28 (1939).

82. World War I brought on the first concerted national effort in propaganda:

The Committee on Public Information, headed by George Creel, was established by executive order on April 14,1917. . . . Information about war activity was collected by the committee and distributed on a huge scale; seventy-five million copies of thirty odd booklets were distributed in several languages; seventy-four thousand speakers (Four Minute Men) made 755,190 speeches; the foreign language press was served with selected articles; [etc.] . . . .

These services cost the taxpayers $\$ 2,083,833$ and were discontinued within twenty-four hours after the Armistice. Biddle, Freedom of Speech and Propaganda, 25 A.B.A.J. 795, 796-97 (1940). For a critique of the Creel Committee, see E. BERnays, Propaganda 27-28 (1928), quoted in $\mathrm{F}$. Biddle, Education and Propaganda 21 (1932). See generally H. Lasswell, Propaganda TECHNIQUE IN THE World WAR (1927); J. Mock \& C. LaRson, Words That Won the WaR (1939).

The apparatus remained dismantled until the Second World War. President Roosevelt established the Office of Facts and Figures, on October 24, 1941, "for the purpose of facilitating the dissemination of factual mformation to the citizens of the country on the progress of the defense effort and on the defense policies of the Government." Exec. Order No. 8922, 3 C.F.R. 1016 (1938-1943 Compilation). See Steele, Preparing the Public for War: Efforts to Establish a National Propaganda Agency, 1940-41, 75 AM. Hist. Rev. 1640 (1970).

On June 13, 1942, OFF was merged with the three-year-old foreign information service, and the Office of War Information was formed. Unlike OFF, which charged itself with providing the public "with whatever information it thought relevant to decisions on questions of principle," OWI's only domestic responsibility was to get the mihtary communiques out as quickly as possible. Z. CHAFEE, supra note 6, at 732 .

83. International propaganda activities are conducted under the United States Infornation and Exchange Act, 22 U.S.C. $\$ \S 1431-1479$ (1976) (originally enacted in 1948), which sanctions a coordinated and effective foreign infonnation bureau. Under authority of that Act, Reorganization Plan No. 8 of 1953, 3 C.F.R. 1030 (1949-1953 Compilation), reprinted in 22 U.S.C. \$ 1461 (1976), established the United States Information Agency. This agency was deemed necessary to combat the massive Communist propaganda which was presenting the world with a warped picture of America.

While the aim of USIA was to present the "truth," Congress specified that the products of the agency could not be distributed for domestic consumption. Information and Exchange Act $\S 501$, as amended, 22 U.S.C. \& 1461 (1979). But see Note, Domestic Availability of Certain United States Information Agency Program Materials, 11 VA. J. INT'L L. 71 (1970) (arguing that Congress did not intend $\S 501$ to be a total bar to domestic distribution). The USIA Appropriations Act for 1973 settled the matter by amending the Act to state clearly that no USIA infonnation should be disseminated within the United States, except that access would be allowed for members of Congress, journalists, and sclolarly researchers, and that "Problems of Communism" could continue to be sold by the GPO. Pub. L. No. 92-352, 86 Stat. 489 (1972). 
shire to disseminate an official ideological view, provided that the State forced no one to participate in such dissemination. ${ }^{84}$ The speech at stake in that case-the "Live Free or Die" motto on New Hampshire license plates-was sufficiently abstract, however, as to have hittle or no bearing on concrete political issues confronting the State's voters. ${ }^{85}$ The Court's holding thus does not stand as an endorsement of the type of state advocacy that would raise serious political establishment concerns.

Between the creation of a permanent propoganda office and the use of a inotto on license plates, however, lies the bulk of political establishment problems. One such problem is publicity for governmental programs-“administrative" or "decentrahzed" bureaucratic publicity. ${ }^{86}$ This publicity serves not only to inform the electorate, but also,

84. See text accompanying notes 70-72 supra.

85. The most analogous establishment of religion case would be that involving the "In God we trust" motto appearing on United States currency. To the extent this motto has received judicial consideration, it has been by way of distinguishing sucl intrusion of religion into government as being de minimus or having lost any religious significance. See Aronow v. United States, 432 F.2d 242, 243-44 (9th Cir. 1970).

86. The distinction between administrative publicity and propaganda may be meaningless considering their effects, but it has been significant from the perspective of Congress. While Congress has never approved a peacetime domestic information agency, it has permitted the individual public relations offices maintained by the diverse and countless individual government agencies. For lists of sucl offices and their publications, see J. MCCAMY, GoverNMENT PUBLICATIONS FOR THE CITIzeN app., at 120-30 (1950); Hanson, Official Propaganda and the New Deal, 179 ANNALS 176, I80-82 (1935).

As early as 1913, government publicity was a subject of congressional action. A rider to a bill relating to the Interstate Cominerce Commission provided that "no money appropriated by this or any other act shall be used for the compensation of any publicity expert unless specifically appropriated for that purpose." 38 Stat. 212 (1913), reworded, Pub. L. No. 89-554, 80 Stat. 416 (codified at 5 U.S.C. $\S 3107$ (1976)). The rider was prompted by a Department of Agriculture bid to hire a publicity expert for the Office of Public Roads. 50 CoNG. REC. 4409 (1913). Congress believed that the government received adequate press coverage without invoking such aid. In 1973, $\S 608(a)$ of the Treasury, Postal Service, and General Government Administration Act, which included funds for the White House Office, provided that "[n]o part of any appropriation obtained in this Act, or of funds available for expenditure by any corporation or agency shall be used for pubhicity or propaganda purposes designcd to support or defeat legislation pending before Congress." Pub. L. No. 92-351, § 608, 86 Stat. 488 (1973).

It is doubtful that these congressional attempts to control the expenditure of funds for publicity or propaganda purposes liave had any appreciable limiting effect. Despite a provision in the annual appropriations bill for the Department of Defense for every year since 1968 stating that "[n]o part of any appropriation contained in this Act shall be used for publicity or propaganda purposes not authorized by Congress," e.g., Pub. L. No. 92-570, § 701, 86 Stat. 1184 (1972), the Pentagon has consistently been given a high public affairs budget. See J. FulBright, THE PENTAGon Propaganda Machine 27 (1970); Forkosch, Freedom of Information in the United States, 20 De Paul L. Rev. 1, 26 n.81 (1971); Lyford, The Pacification of the Press, The Center MagaZINE, 24, 27-28 (Mar./Apr. 1973). Department of Defense figures for 1970 showed that 4,430 of its eniployees were working in some way to sliape public opinion. Thus, Defense liad twice as many public relations people as the United States Inforination Agency lad overseas, but without the same restrictions. J. FULBRIGHT, supra, at 149-50. 
on occasion, to persuade it. ${ }^{87}$ For example, the Department of the Army's regulations pertaining to public information activities provide that the goals of these activities shall be to "develop public esteem and respect for the Army, . . . gain public understanding for the Army's role, ... . [and] inspire public confidence in the Army's ability to accomplish its mission." 88

Under the prohibition of an implied political establishment clause, regulations that permit the dissemination of information to improve an agency's image or to enhance support for its policies would be impermissible-botlı as to purpose and effect. Tlere is no "political purpose" basis for objecting to governmentally produced messages that merely inform the public about important regulatory laws. If these messages endorse the merits of the regulation, however, a political establishment problem exists. ${ }^{89}$

The Army's regulations thus would not survive a constitutional challenge on political establishment grounds. The purpose of these regulations-to infiuence public debate over the Army's proper role and capabilities-would be clearly improper. Moreover, facial redrafting of the regulations to eliminate the explicit mandate for biased information might not save them. True, the regulations would no longer lave an improper purpose. If they contmued to liave a practical political impact, however, a court would have to strike them down.

Political estabhshment problems also appear in the operation of

87. Consider the factual backdrop of P.A.M. News Corp. v. Butz, 514 F.2d 272 (D.C. Cir. 1975), in which the court held that the Department of Agriculture's institution of a direct extension news wire service did not violate the first amendment rights of a private corporation whose provision of such services antedated that of the Department. The case exemphifies governmental dissemmation of factual data based on government research or recordkeeping-weather reports, crop records, census figures, cancer research, etc. Any interpretation to be done by the government presumably would be of an objective scientific nature, but research, particularly social science research, may not be pohtically neutral. See Orlans, The Political Uses of Social Research, 394 ANNALs 28, 31 (1971).

For discussion of propaganda functions, see J. Fulbright, supra note 86; Herring, Official Publicity Under the New Deal, 179 ANnALs 167, 168 (1935). But see Z. CHAFEe, supra note 6, at 774-75; Fainsod, supra note 81, at 522-23; Iustitute of Living Law, Combatting Totalitarian Propaganda: The Method of Enlightenment, 27 MiNN. L. REv. 545, 560-61 (1943).

88. 32 Fed. Reg. 18,089 (1967). The Army regulations were published in the Code of Federal Regulations, 32 C.F.R. $\$ 504.4$ (1977), until 1978 when they were removed (but not invalidated), ironically, because they were deemed not to be of sufficient interest or importance to the public to warrant such publication. 43 Fed. Reg. 26,443 (1978).

89. That this purpose exists is illustrated by the statement of one Pentagon public relations official that:

our mission was identical to that of any commercial advertising agency: to "push" our product . . . as hard as we could-to capitalize on its successes, and to conceal its blunders. ... We were not concerned primarily with truth or accuracy (except in spelling the names of officers), and we were not adverse to releasing false information when advantageous.

Newsday, Nov. 21, 1970; Forkoscl,, supra note 86, at 33-34 n.100. 
the communications media. The federal government regulates and gives financial support to much of the media. As a consequence, media members - im particular, public broadcasters ${ }^{90}$ - may be susceptible to the political bias of the government.

There are presently three levels of government support for broadcast stations. Private commercial stations receive the lowest level of support: an FCC license grants them a monopoly to broadcast on a particular frequency. Private noncommercial stations receive more assistance. The government funds programming for these stations through the Corporation for Public Broadcasting (CPB). ${ }^{91}$ Fmally, the greatest support goes to government noncommercial stations. They receive all of tlie funding aid that private noncommercial stations do and, additionally, are owned and operated by agencies of state or local governments.

It is clear that as government support for a particular broadcaster increases, the political establishment concerns also mcrease. ${ }^{92}$ If, however, the government requires its more heavily supported broadcasters to make a more neutral political presentation, then the concern about government establishment of political viewpoints dimimishes considerably. Thus, one would expect the level of regulatory safeguards designed to prevent political estabhishments to vary according to the level of government support that a broadcaster receives.

The regulatory framework promulgated by Congress and the FCC to promote a balanced presentation of viewpoimts on political issues correlates only imperfectly witly the amount of support given the regulated broadcasters. It establishes only two levels of restriction. Private commercial stations must comply solely with the fairness doctrine, which requires balanced coverage of controversial public issues ${ }^{93}$ and "equal time" rules. On the other hand, the Public Broadcasting Act of 1967 furtlier prevents private noncommercial and governınent stations

90. See, e.g., Community-Service Broadcasting of Mid-America, Inc. v. FCC, 593 F.2d 1102 (D.C. Cir. 1978) (en banc); Accuracy in Media, Inc. v. FCC, 521 F.2d 288 (D.C. Cir. 1975). The term "public broadcasting" refers to programming by noncommercial radio and television stations which are either publicly owned or are owned by nonprofit private organizations and which reccive some degree of federal financial support. See generally Accuracy in Media, Inc. v. FCC, 521 F.2d 288, $291-92$ (D.C. Cir. 1975); Note, "Balance and Objectivity" in Public Broadcasting. Faircr than Fair?, 61 VA. L. Rev. 643, 644-49 (1975).

91. The CPB was created by the Public Broadcasting Act of 1967, 47 U.S.C. $\$ 396$ (1976).

92. The same relation may be derived by viewing the question from a free expression point of view. Because all broadcast stations are protected to some extent by the first amendment, see Community-Service Broadcasting of Mid-America, Inc. v. FCC, 593 F.2d 1102 (D.C. Cir. 1978), application of a political establislment prohibition conflicts with stations' free expression rights, and some balancing of interests is necessary. The more direct the links between a station and the government, the less compelling are its free expression interests, and the more severe are the political establishment dangers.

93. Accuracy in Media, Inc. v. FCC, 521 F.2d at 295-96. 
from "editorializing" or "support[ing] or oppos[ing] any candidate for political office." 94 - In addition, the CPB's funding discretion is statutorily limited to "strict adherence to objectivity and balance in all prograins or series of prograins of a controversial nature." $" 95$

It is arguable that the level of government support that private noncommercial and perhaps even commercial stations receive turns the exercise by such stations of editorial prerogatives into government speech. ${ }^{96}$ This arguinent, however, was rejected in Network Project $v$. $C P B ;{ }^{97}$ the court exphicitly found that the activities of $C P B$ and the

94. 47 U.S.C. \$ 399(a) (1976). See Lindsey, Public Broadcasting: Editorial Restraints and the First Amendment, 28 FED. COM. B.J. 63, 79-82, 94-95 (1975) (setting forth the section's legislative history and arguing that its purpose was to prevent criticisin of government).

95. 47 U.S.C. \& $396(\mathrm{~g})(\mathrm{l})(\mathrm{A})(1976)$.

On the basis of pervasive federal involvement in the creation, funding and management of the CPB, that organization is characterized here as a government entity for purposes of identifying aid to private disseminators. See Canby, The First Amendment and the Staie as Editor: Implications for Public Broadcasting, 52 TEXAS L. Rev. 1123, 1126 (1974).

In his concurrence in Colunbia Broadcasting v. Deinocratic Comm., 412 U.S. 94 (1973), Justice Douglas seemed to suggest a more stringent requirement of balanced presentation for government stations, presunably constitutional in nature:

If these cases involved [the $\mathrm{CPB}$ ] we would have a situation couparable to that in which the United States owns and inanages a prestigious newspaper. . . . The Government as owner and manager would not ... be free to pick and choose such news items as it desired. . . . Politics, ideological slants, rightist or leftist tendencies could play no part in its design of programs. . . . More specifically, the programs tendered by respondents ... could not then be turned down.

....

If a TV or radio hicensee were a federal agency . . ., precisely the situation of the [CPB] . . , it would be bound to disseminate all views.

Id. at 149-50 (Douglas, J., concurring).

Although this statement could be read to say that throughout its broadcasting day a government station must operate as an open public forum and its managers may not exercise editorial judgment, when placed in context, it appears to mandate nondiscrininatory public access only to that portion of the station's broadcast time which it already had opened up for purchase.

Recently, in Network Project v. Corporation For Public Broadcasting, 45 RAD. Reg. 2d (P \& F) 701 (D.D.C. 1979), the court concluded that "public television does not constitute a public forum:"

In carrying out the task [of program funding] the defendants are required to apportion a finite resource-money. This dictates that $\mathrm{CPB}$ and $\mathrm{PBS}$ of necessity must engage in editorial decisions concerning the content of programs which are urged upon thein. This, of course, does not give the defendants a free rein to discriminate agamst certain types of programs or to seek to promote certain messages over others. And where a pattern of discrimmation is sufficiently alleged, recourse nnay be had to First Amendment reinedies.

Id. at 714. The court based its conclusion on the previously discussed analysis in Advocates for Arts v. Thompson, 532 F.2d 792 (1st Cir.), cert. denied, 429 U.S. 894 (1976).

96. Compare Columbia Broadcasting v. Deenocratic Comm., 412 U.S. 94, 170 (1973) (Brennan, J., dissenting) with id. at 114 (Burger, C.J.).

97. 45 RAD. REG. 2d (P \& F) 701, 706-12 (D.D.C. 1979). For an illustration of a much lower threshold of state action in the broadcasting field, see Writer's Guild of America, West, Inc. v. FCC, 423 F. Supp. 1064, 1140-43 (C.D. Cal. 1976) (institution of "family viewing hour" by private networks found to be state action when done in response to implied threats of reprisal by FCC Chairman). It is also contrary to a provision in the Public Broadcasting Act stating that the corporation "will not be an agency or establishment of the United States Government." 47 U.S.C. \$396(b) (1976). There is no reason to suppose that Congress intended to free the CPB froun 
Public Broadcasting System do not constitute state action. Therefore, I will assume the only type of stations engaging in government dissemination are government stations.

The question here is what level of restriction on government noncommercial stations is constitutionally required under an implied political establishment clause. It is clear that the prohibition against editorializing, along with the protections afforded by the fairness doctrine, are adequate to prevent government promulgation of a political position. The fairness doctrine and the so-called "equal time rules" 98 assure that if a station presents one side of an issue it must present all sides. The only remaming political establishment problem is the possibility that the station's management will itself present one side, giving that side an advantage in prestige. The ban on editorializing and supporting or opposing political candidates, however, prevents this possibility.

Finally, the requirement that each program or series funded by the CPB be strictly objective and balanced obviously imposes a stricter control than the fairness doctrine, ${ }^{99}$ which requires only that the totality of a station's programming provide a roughly fair presentation of a subject. Because the fairness and antieditorializing restrictions at the individual station level provide adequate protection agamst a challenge on political establishment grounds, such an additional requirement appears to be unnecessary for this purpose.

\section{Dissemination to Students in Public Schools \\ a. The Nature of the Debate}

Government dissemination of political views occurs in the public school system. Statutes or regulations that require public school curricula to propagate particular ideologies-for example, anticommunism, patriotism, or free enterprise-reflect the efforts of various groups to harness public education for imdoctrination purposes. In recent years there has been particular ferment over attempts to purge textbooks and

otherwise applicable constitutional limitations, nor, given the Supreme Court's role as the ultimate interpreter of constitutional rights, would Congress have had the authority to do so. But $c f$. Chrisman v. Sisters of St. Joseph of Peace, 506 F.2d 308 (9th Cir. 1974) (upholding amendment to HillBurton Act prohibiting courts from using receipt of federal funds as basis for compelling hospital to perform a sterilization or abortion where this is forbidden on the basis of religious or moral convictions).

98. 47 U.S.C. $\$ 315$ (1976). See Federal Communications Commission, Primer on Political Broadcasting and Cable Casting, [1978] 43 Rad. Reg. 2d (P \& F) 1353, 1359-60, 1381-84 (heremafter cited as PRIMER).

99. See text accompanying notes 38-39 supra. 
curricula of "objectionable" material. 100

To some degree the problem of political establishment may be inlerent in the very concept of public education. ${ }^{101}$ The ensuing analysis assuunes, liowever, that a system of public education may function consistently with the imperatives of an implied political establishment clause.

There is inuch current debate over the proper role of public education in a deinocratic society. For some, a major purpose of public schools is to produce graduates who share a fundamental commitunent to "our way of life." 102 Others oppose this thinking and einphasize the need to produce graduates capable of imdependently and critically assessing American society. ${ }^{103}$

The political establishment prohibition would have a significant impact on the outcome of this debate. Establishment probleuns exist whenever a public school advocates a particular political viewpoint to the exclusion of others. Under the test of constitutionality, courts

100. See Williams v. Board of Educ., 388 F. Supp. 93, 94-95 (D.W.Va. 1975); Scliember, Textbook Censorship-The Validity of School Board Rules, 28 ADMIN. L. REv. 259-60 (1976).

101. The concern with lack of diversity lias been a factor in evoking proposals for decentralization of large urban schools, i.e., "community control," and for initiation of educational voucher or other plans under whicls parents could obtain education for their children at schools of their choice. See J. Coons \& S. Sugarman, Education By Choice: The Case for Family ConTROL (1978); M. Fantini \& G. WeInStein, Making URBan Schools Work 9 (1970); Fantini, Community Control and Quality Education in Urban School Systems, in COMMUNITY CONTROL OF Schools 40 (H. Levin ed. 1970); Areen, Education Vouchers, 6 HARv. C.R.-C.L. L. REv. 466, 469 (1971); Note, Education Vouchers and Curriculum Control: The Parent Versus the State, 52 B.U. L. REv. 262, 266 (1972).

102. Goldstein, The Asserted Constitutional Right of Public School Teachers to Determine What They Teach, 124 U. PA. L. Rev. 1293, 1342-44, 1350-51 (1976). But see Van Alstyne, The Constitutional Rights of Teachers and Professors, 1970 DUKE L. J. 841, 856-58.

103. See W. Biddle, Propaganda and Education (1932); J. Childs, American Pragmatism and Education (1956); E. Friedenberg, The Vanishing Adolescent 39-42 (1960); P. Rich, Education and Human Values 3, $15-16$ (1968); Sexton, The American School 76-89 (1967); Catlin, The Role of Propaganda in a Democracy, 179 Annals 219 (1935); Childs, Should the School Seek Actively to Reconstruct Society?, 182 AnNals 1, 5 (1935); Dewey, Education as Politics, 32 New Republic 139 (1922); Katz, The Present Moment in Educational Reform, 41 HaRv. Educ. Rev. 342, 356 (1971); Wooddy, Education and Propaganda, 179 ANnals 227 (1935).

The Supreme Court has addressed this issue only indirectly. In Ambach v. Norwick, $99 \mathrm{~S} . \mathrm{Ct}$. 1589 (1979), the Court, in dicta, described the role of public education. It lield that a state's refusal to employ as elementary and secondary school teachers aliens who are eligible for United States citizenship but who refuse to seek naturalization was not a denial of equal protection. Writing for the Court, Justice Powell emphasized the role of public education in "inculcating fundamental values necessary to the inaintenance of a deinocratic political system." Id. at 1599. The citizenslip requirement was lield rational simce "a teaclier lias an opportunity to influence the attitudes of students toward government, the political process, and a citizen's social responsibilities." Id. at 1596. Cf. Bellotti v. Baird, 99 S. Ct. 3035 (1979), in whicl Justice Powell, writing for a four meinber plurality, addressed the states' role in public education vis-d-vis parental rights and stated that "affirmative sponsorship of particular ethical, rehigious, or political beliefs is sometlimg we expect the State not to atteinpt in a society constitutionally committed to the ideal of individual liberty and freedoin of choice." Id. at 3045. 
would examine such advocacy under a strict scrutiny standard. The inquiry becounes, then, whether the schools can advance a coinpelling countervailing interest that outweighs the interest in prohibiting establishments.

The schools might assert that there is a societal interest in promoting certain political values in the nation's youth. The claim is that the infusion of such values in the educational process is the only satisfactory ineans for accoinplishing this very important objective.

This claim has several difficulties. First, it assumes the existence of "correct," or at least uniformly acceptable, pohtical values. Short of general concepts of social responsibility, however, no such values exist. Moreover, atteunpts to indoctrinate students with values of debatable acceptability inay raise coinpelled adherence problems. ${ }^{104}$ Second, alternative means for instilling values in youth clearly exist. Families, religious organizations, youth groups, and other institutions adequately perform this function. And in view of the lack of general consensus about important values, means such as these which provide a choice ainong ideological orientations are nore consistent with free speech concerns.

In any event, the fundainental interest in preventing political estabhshments outweighs this asserted social interest. The use of public schools to instill political values poses a serious threat to the marketplace of ideas and the integrity of the democratic process. Children are particularly susceptible to political indoctrination. As a consequence, the impleinentation of a political establishment prohibition in this setting is crucial.

Patriotic sentiments of a generalized nature that public schools instill in students during the earliest years of education are not a proper subject for judicial intervention under the political establishment clause; these political viewpoints are not sufficiently discreet to be actionable. Presentation of inore specific political viewpoints at the junior high and high school levels, however, is a inatter of concern. Students at this level are inature enough to understand specific political concepts, but are not so sophisticated as to challenge all that they are taught. They are thus susceptible to indoctrination. Absent a political

104. The free speech rights threatened here are those of the parents; they may assert that they are being "forced" to submit their children to indoctrination with ideas with which they, the parents, do not agree. The right of parents to instill values in their children free froin the interference of public schools was confirmed in a religious context in Wisconsin v. Yoder, 406 U.S. 205, 213-14 (1972). Although parents with minority political views are ostensibly entitled, as are parents desiring a religious orientation in their children's education, to send their children to private schools, in both cases, financial limitations may make this option illusory. Such parents are entitled to the same degree of governinent neutrality in the instruetion of their children as are religiously oriented parents. 
establishment prohibition, the government could constitutionally influence tlre political outlook of new eighteen-year-old voters as they prepare to enter the political process. Furthermore, unost secondary school students do not attend college, ${ }^{105}$ where exposure to and critical analysis of diverse viewpoints takes place. Thus, indoctrination at the secondary school level inay have a lasting impact, seriously distorting the political process. The alleged benefits of using public education as a ineans of instilling values in children cannot justify such distortion.

\section{b. Applying the Prohibition}

i. Curriculum Content. Many states have statutes that require indoctrination in "patriotisin" and "Americanism" or specify that the curriculuun shall einphasize the virtues of the "free enterprise systen1." 106 Other laws specify that the curriculuun shall portray the evil of Communisin or shall not present Communism favorably. ${ }^{107}$ These curriculuin requirenients have an improper purpose and primary effect under the political establishment prohibition; they are aimed at advancing a particular political viewpoint and have precisely that effect.

There are no recorded cases that consider these statutes or political indoctrination in curriculuin formulation generally. Epperson v. Arkansas, ${ }^{108}$ however, provides an analogous constitutional limitation on religious indoctrination. The Court held that the religious establishment clause barred the State fron 1 eliminating the theory of evolution fron1 classrooin discussions of man's origin. ${ }^{109}$ By atteinpting "to blot out a

105. In 1976, out of a total of $2,987,000$ students graduating from high school, $1,458,000$, or 48.8\%, enrolled in college. HEW National Center for Education Statistics, Digest of Education Statistics, 1977-78, 33, 38, 44 (1978).

106. Arkansas requires that both public and private primary grade schools offer at least one hour per week of instruction in all grades on American history: "The instilling into the hearts of the various pupils of an understanding of the United States and a love of country and of a devotion to the principles of American government shall be the primary object of such instruction. . . " Ark. Stat. Ann. § 80-1613 (1960). See also Ala. Code § 16-40-3 (1975); Ariz. Rev. Stat. Ann. § 15-1025(A) (West 1975); Ga. Code AnN. § 32-171 (1976); Minn. Stat. AnN. $\S 126.08$ (West 1979); Miss. CODE ANN. § 37-13-5 (1973).

In Meltzer v. Board of Pub. Instruction, 577 F.2d 311 (5th Cir. 1978), cert. denied, 439 U.S. 1089 (1979), the court considered an establishment clause challenge to FLA. STAT. ANN. $\$ 231.09$ (2) (Hanson 1977), directing teachers to inculcate Christian virtues in their students. The per curiam en banc decision found that there was no threat of enforcement of the statute sufficient to create a case or controversy. Seven of the fourteen judges on the panel reached the merits and found the statute unconstitutional.

107. Nebraska requires high school civics courses which, among other things, teach "[t] $]$ he benefits and advantages of our form of government and the dangers and fallacies of Nazisin, Communism, and similar ideologies." NeB. Rev. Stat. § 79-213(5)(b) (1976). See also AlA. Code $\S 16-40-3$ (1975); LA. Rev. Stat. ANN. § 17:2851 (West 1963); N.H. Rev. Stat. ANN. $\S$ 191:1 (1978); N.Y. Educ. LAw § 3204(3) (West 1970).

108. 393 U.S. 97 (1968).

109. Id. at 109. 
particular theory," the State had placed the weight of its educational system behimd an alternative explanation. ${ }^{110}$

ii. Textbook Selection. The states fall into three different groups im methods of textbook selection: "those in which the State Board of Education is the adopting agency, those which provide for local choice, and those which have set up commissions or committees to recommend the books to be adopted."111

Some laws prohibit the use of textbooks which take a position contrary to the state's. Kentucky, for example, prohibits any textbook or printed material which "criticizes" or "could be deemed discrediting . . . to, any legally constituted school or system of healing,-science or profession."112 In California, public schools may not adopt any instructional materials containing "[a]ny matter reflecting adversely upon persons because of their race, color, creed, national origin, ancestry, sex, or occupation."113

Other state laws appear more directed at achieving balanced presentation. Thus, Alabama generally forbids adoption of any books "of a partisan character."114 In the field of ininority group relations, some states now require that social studies and other course books adequately represent the achieveinents and contributions of wonnen and of racial and ethnic ininorities. ${ }^{15}$ A recently enacted Tennessee law ${ }^{116}$

110. Id. Cf. Mercer v. Michigan State Bd. of Educ., 379 F. Supp. 580, 585-86 (E.D. Mich.), affd mem., 419 U.S. 1081 (1974) (upholding statutory prohibition against teaching birth control in public schools).

The opinion in Epperson strongly inplied, however, that the State had no constitutional obligation to provide students with a course on this subject. There is thus no constitutional basis for overriding a state's decision to exclude a particular subject area from the public school curriculum as long as the effect is not to advance an alternative viewpoint. In Meyer v. Nebraska, 262 U.S. 390 (1923), the Court considered a statute that forbade foreign language instruction to students below the ninth grade. It overturned the conviction of a parochial school teacher under this statute on the ground that the statute constituted a deprivation of her liberty without due process. Id. at 403. The Court emphasized, however, that petitioner had not challenged "the state's power to prescribe curriculum for institutions which it supports" and that this matter "was not within the scope of the present controversy." Id. at 402 . It is most unlikely that the Court would have held, for example, that the Constitution precluded a public school system from delaying foreign language instruction until after the eighth grade, or from disciplining a teacher who insisted on doing otherwise.

111. Reutter, The Law and the Curriculum, 20 L. \& CONTEMP. Prob. 91, 115 (1955). See also V. Thayer \& M. Levit, The Role of the School in American Society 65-66 (1966); Cole, $A$ Legal Look at Style and Substance in the Classroom: A Comment, 2 J. L. \& Educ. 313, 321, 323 (1973).

112. KY. Rev. STAT. $\$ 158.180$ (1971) (repealed 1978).

113. CaL. Educ. Code $\$ 60044$ (West 1978).

114. Ala. Code tit. 52, $\$ \$ 433(6)$, (6a) (1977).

115. Cal. Educ. Code $\$ 60040$ (West 1978); Mich. Comp. Laws ANN. $\$ 380.1173$ (West 1976); NEB. Rev. Stat. \$ 79-213(1)(a) (1976).

116. TENN. CODE ANN. \& 49-2008 (1977). 
requires that any public school biology text which raises the question of the origin of man include all relevant theories and not present any such theory as fact. ${ }^{117}$

The preceding analysis of curriculum controls would certainly prohibit a statute, regulation, or de facto policy that forbids or requires the use of textbooks that contain a particular political viewpoint. By contrast, statutes that mandate balanced textbook treatinent of controversial issues-a requirement of textbook fairness ${ }^{118}$ - would be valid. Moreover, to the extent that centralization of the textbook selection function is inescapable, the political establishment prohibition would mandate this requirement of balance.

An examination of the inost difficult example-attempts to purge textbooks of disparaging racial, sexual or other stereotypes-best illustrates analysis under the political establishment clause. The attributes and position in society of a defined group is clearly a matter of political controversy, as the recent debates over Regents of the University of California v. Bakke ${ }^{119}$ and the Equal Rights Amendment suggest. The political establishment clause would require balanced curricular and textbook treatment of the various viewpoints on race relations and women's rights. It is possible that in some instances the government would design its textbooks and curriculum to present only a positive image of a particular group. ${ }^{120}$ Courts would have to prohibit such efforts, however, as a political establishment.

The government could argue that, unlike similarly forbidden negative portrayals, the enhancement of a minority group's status through the school curriculum is proper because of the compelling state interest

117. The statute was held to violate the establishmeut clause by both the Sixth Circuit and the Tennessee Supreme Court. Daniel v. Waters, 515 F.2d 485 (6th Cir. 1975); Steele v. Waters, 527 S.W.2d 72 (1975). See also Wright v. Houston Indep. School Dist., 366 F. Supp. 1208 (S.D. Tex. 1972), affd, 486 F.2d 137 (5th Cir. 1973) (upholding science course in which only evolutionary theory is taught); Crowley v. Smithsonian Inst., 422 F. Supp. 725 (D.D.C. 1978) (upholding exhibition on evolution). But see Note, Freedom of Religion and Science Instruction in Public Schools, 87 YALE L.J. 515 (1978).

118. The blatantly religious character of the Tennessee statute relating to theories of creation prevented seriously considering it a textbook fairness statute. The statute expressly singled out "the Genesis account in the Bible" and excluded "all occult and satanical beliefs of human origin." Daniel v. Waters, 515 F.2d 485, 491 (6th Cir. 1975). However, to the extent there is reputable scientific authority supporting an antievolutionary theory of man's origin, a statute requiring inclusion of this minority scientific theory in biology textbooks would present little constitutional difficulty. See generally D. Nelkin, Sclence TeXtbook Controversies AND the Politics of EQual Time (1977). Moreover, there also would be no constitutional obstacle to a requirement that textbooks inform students that there exists a substantial body of religious opmion which disputes the theory of evolution.

119. 438 U.S. 265 (1978).

120. California's legislation, supra notes 113,115 , has been characterized as requiring that textbooks portray women in a positive light and forbidding the use of books which treat women as inferior. See Comment, Sex Discrimination: The Textbook Case, 62 CALIF. L. Rev. 1312 (1974). 
in eliminating discrimination. Further, the state could design a "positive portrayal" policy to remedy consequences arising from prior intentional use of textbooks that contained adverse racial or sexual stereotypes. As a matter of constitutional reinedial law, however, compensatory action designed to offset stereotyping presently appears to be invalid. ${ }^{121}$ This action involves inore than an arguably proper attempt to approximate conditions that would have existed but for the adverse stereotyping. ${ }^{122}$ Instead, it serves to indoctrinate young citizens with a different set of beliefs. Such imdoctrination is actually the perpetuation of an existing evil, not a remedy. It is no inore permissible for government to impose as ortlodoxy what nost consider enlightened thinking than it is to impose currently unpopular views.

\section{Dissemination to Military Personnel}

Dissemination to military personnel presents special political establishment considerations. In particular, the government can argue that political imdoctrination of inilitary personnel is necessary to produce loyal and effective anned forces. This countervailing interest conceivably could outweigh the imterest im preventing government political advocacy.

Recent decisions about free speech in the military reveal that first amendinent protections apply to inilitary persomiel. The Supreme Court lias stated, lrowever, that "the different character of the military mission requires a different application of these protections." 123 This "differing cliaracter," combined with the fact that today's military forces consist entirely of volunteers who have less basis to complain of coercion than do either conscripts or public school students, presents a strong argument that courts would have to uphold inany forms of political speech by the military. ${ }^{124}$

Government indoctrination, however, nay conflict with the first

121. See Regents of Univ. of Cal. v. Bakke, 438 U.S. 265 (1978) (Justice Powell finding that remedying past societal discrimmation was not a sufficiently compelling interest to justify offsettimg racial discrimmation); Limmark Assocs., Inc. v. Willingboro, 431 U.S. 85 (1977) (ordinance forbidding "For Sale" signs unconstitutional because important objective of preventing "white flight" imadequate to justify stifiing flow of information).

122. Cf. Milliken v. Bradley, 433 U.S. 267, 282 (1977); Pasadena City Bd. of Educ. v. Spangler, 427 U.S. 424, 434-35 (1976); Milliken v. Bradley, 418 U.S. 717, 744-46 (1974).

123. Parker v. Levy, 417 U.S. 733, 758 (1974).

124. Judge Bazelon's dissent in Carlson v. Schlesinger, 511 F.2d 1327, 1335 (D.C. Cir. 1975), provides an opposing view. The majority in that case held that the Army could permissibly prohibit the circulation of "end the war" petitions in a Vietnam combat zone in order to maintain morale and disciphine. Judge Bazelon disapproved that holding and seemed to consider propaganda in the mihtary inherently evil. He stated that under the court's rationale, the government arguably "has, in order to maintain an efficient fighting force, the right to eliminate through exclusive propagandizing efforts any disagreement among soldiers with military policy." $I d$. at 1338. 
amendment rights of military personnel. The question becomes, then, what standard is appropriate to determine when a government dissemination of this sort is impermissible. In Carlson v. Schlesinger, ${ }^{125}$ the majority applied what appeared to be a "rational basis" test in finding it permissible to prohibit the circulation of "end the war" petitions in a Vietnam coinbat zone. ${ }^{126}$ It held that courts should not invalidate the prohibition of antiwar literature "unless the military's infringement upon first amendment riglits is manifestly unrelated to legitimate inilitary interests." 127

In Anderson v. Laird, ${ }^{128}$ however, two of the three judges applied a stricter standard. The question in that case was whether compulsory chapel attendance at United States military academies was an unconstitutional establishment of religion. Chief Judge Bazelon found that no balancing test was necessary since pertment Supreme Court decisions "refer[red] to no overriding secular imterests which could ever justify a governmental imposition of those religious activities which the Clause was written to abolisli." 129 Judge Leventhal, in his concurring opinion, found it unnecessary to resolve the question whether such activities were illegal per se. He applied a strict scrutiny-compelling state interest standard and found tliat compulsory chapel attendance was "not necessary in the inaking of an officer." 130

A difference between religion and politics suggests different treatinent of their establishment by the military. The military can instill useful values found in religion througli nonreligious instruction. Only tlurough political advocacy, however, can the military inspire the loyalty necessary to its effectiveness, as recognized in Carlson. This difference suggests that the appropriate test of the acceptability of a political establishment in the military is whether it bears a rational relationship to the legitimate state interest of cultivating loyalty among military personnel. Finally, even if courts consider a strict scrutiny test appropriate, the military's need to cultivate loyalty constitutes a sufficiently compelling state interest to satisfy that standard. ${ }^{131}$

125. 511 F.2d 1327 (D.C. Cir. 1975)

126. Id. at 1333.

127. Id.

128. 466 F.2d 283 (D.C. Cir. 1972).

129. Id. at 290 .

130. Id. at 310-14 (Leventhal, J., concurring).

131. See Greer v. Spock, 424 U.S. 828 (1976) (regulation permitting military commander to disapprove on-base dissemination of publications deemed dangerous to loyalty, discipline or morale of troops held constitutional when invoked in nondiscrimmatory fashion). $C f$. Blaumeuser v. Andrews, 473 F. Supp. 767 (E.D. Wis. 1979) (compelling interest in excluding self-proclaimed Nazi from college ROTC program). 


\section{B. Government Support for Private Advocacy}

The pohtical establishment prohibition would forbid the government from allocating a public resource or benefit on the basis of an individual's or group's political views. To consider such a factor would, by definition, satisfy the "political purpose" test of establishment. ${ }^{132}$

The Supreme Court has already prohibited this method of government allocation on other grounds. In Police Department v. Mosley, ${ }^{133}$ the Court invalidated a statute which forbade public picketing of schools over all controversies except labor disputes: "under the Equal Protection Clause, not to mention the First Amendment itself, government may not grant the use of a forum to people whose views it finds acceptable, but deny use to those wishing to express less favored or more controversial views." 134 This analysis turns on the law's negative impact on those denied access to a public resource rather than on the unfair subsidy to competing advocates. Nevertheless, equal protection analysis is preferable to political establishment analysis in cases where the government expressly uses political criteria to allocate resources; forsaking familiar modes of analysis to articulate the problem in political establishment terminology offers little advantage.

Political establishment analysis remains necessary for another category of government assistance problems. These are the more difficult cases wliere the decision to provide aid is made with complete political neutrality. The political purpose test of establishment is not met here, but there may be either an impermissible primary effect or excessive entanglement.

\section{Public Forums}

Normally there is no establishment problem when a city rents a municipal auditoriuin for a single evening to an organization that plans to dissemmate politically controversial views. The primary effect of opening the public forum on a nondiscriminatory basis is to enhance

132. Two clear examples of such improper consideration are subsidies for private publication of books favoring United States foreign policy positions, see T. EMERSON, supra note 5, at 712; and Department of Defense assistance to private production of only those motion pictures believed to serve "the best interests of the country," see J. FULBRIGHT, supra note 86, at 110-25; Shain, Shooting Wars, Human Behavior-The Magazine of the Social Sciences, Aug., 1973 , at 64.

133. 408 U.S. 92 (1972).

134. Id. at 96. In Speiser v. Randall, 357 U.S. 513 (1958), the Court held that "a discriminatory denial of a tax exemption for engaging in speech [advocacy of force to overthrow the government] is a limitation on free speech." Id. at 519. See also Communist Party v. Whitcomb, 414 U.S. 441, 449-50 (1974) (ballot access); Baird v. State Bar, 401 U.S. 1, 6 (1971) (bar admission); Keyishian v. Board of Regents, 385 U.S. 589, 605-06 (1967) (public employment). Cf. Niemotko v. Maryland, 340 U.S. 268, 272 (1951) (rehigious discrimination in access to public forum). 
the marketplace of ideas, not to support any one viewpoint. ${ }^{135}$ If the supervising agency has given no consideration to the content of expression and has accorded all groups equal treatment over time, groups will probably use the forum to present most sides of any given debate. ${ }^{136}$ Allocation of control over the forum to a particular group on a nondiscrimimatory but long-term basis, however, presents a inore difficult situation.

In Gilmore v. City of Montgomery, ${ }^{137}$ the Court addressed the implications of monopohstic use of a public facility, observing that "[i]f ... the city or other governmental entity rations otherwise freely accessible recreational facilities, the case for state action will naturally be stronger than if the facilities are simply available to all comers without condition or reservation." 138 The Court's statement recognized that there is a major qualitative difference between allocating scarce time in a municipal facility to, for exainple, a "whites only" group for a day and making the same allocation for an entire summer. ${ }^{139}$ Prolonged control of a public foruin by a group advocating an identifiable pohitical position would produce the primary effect of applying public resources for the advanceinent of one viewpoint to the exclusion of competing groups with other viewpoints.

At first glance, this analysis appears to conflict with several decisions that define the constitutional status of student-operated newspapers and radio stations funded by public educational institutions. ${ }^{140}$ It would suggest that public institutions are constitutionally able to create and fund student communications facilities only if students operate those facilities as open public foruns available for the dissemination of all viewpoints. ${ }^{141}$ An "open forum" requirement, however, is inconsis-

135. National Socialist White People's Party v. Ringers, 473 F.2d 1010, 1016-17, 1019 (4th Cir. 1973).

136. "We are confident that if the high school auditorium is made available to all groups, the very diversity and complexity of the views expressed, taken in bulk, will cure any incidental offcial identification attendant upon the use of the building for the articulation of extreme or abusive speech." Id. at 1018.

137. 417 U.S. 556 (1974).

138. $I d$. at 574 .

139. The Ringers court found that "[n]o case suggests that a group which discriminates in selecting its membership can be barred from occasional uses of the streets, parks and public meeting places of a community." National Socialist White People's Party v. Ringers, 473 F.2d 1010, 1016 (4th Cir. 1973) (emphasis added). See also Resnick v. East Brunswick Township Bd. of Educ., 77 N.J. 88, 117, 389 A.2d 944, 958 (1978) (upholding after-school use of public school property by religious groups for worship services). The court cautioned that "lengthy use . . a at some point . . . will surely inplicate the Board in the pronnotion of religion." Id.

140. See, e.g., Schiff v. Williams, 519 F.2d 257, 260 (5th Cir. 1975); Joyner v. Whiting, 477 F.2d 456, 460 (4th Cir. 1973); Bazaar v. Fortune, 476 F.2d 570, $574-75$ (5th Cir. 1973); Antonelli v. Haminond, 308 F. Supp. 1329, 1337 (D. Mass. 1970).

141. See Gambino v. Fairfax County School Bd., 564 F.2d 157, 158 (4th Cir. 1977); Mississippi Gay Alliance v. Goudelock, 536 F.2d 1973 (5th Cir. 1976), cert. denied, 430 U.S. 982 (1977); 
tent with the kind of editorial discretion that the freedom-of-speech clause protects in just this context. ${ }^{142}$

The imposition of an "open forum" or some other fairness requirement on student-operated, publicly funded media would be appropriate and necessary only under one condition: that students remain in control of a facility for such a "prolonged period" that the primary effect is the estabhshment of a pohtical orthodoxy. The nonnal tenure of a student control group, however, is not sufficiently long to have that effect. Over time, different controlling students will espouse different viewpoints. ${ }^{143}$ An open forum requirement is thus inappropriate; and the apparent conflict with the students' free speech interest does not exist.

The federal government has allowed at least one type of public forum to remain under the control of a simgle group for periods long enough to cause serious primary effect concerns. The FCC, through its licensing practices, grants each broadcaster an exclusive right to broadcast on a wave length for what amounts to an indefinite period. ${ }^{144}$ Ad-

Avins v. Rutgers, 385 F.2d 151 (3d Cir. 1967), cert. denied, 390 U.S. 920 (1968); Arrington v. Taylor, 380 F. Supp. 1348 (M.D.N.C. 1974), aff'd mem., 526 F.2d 587 (4th Cir. 1975); Panarella v. Birenbaum, 32 N.Y.2d 108, 296 N.E.2d 238, 343 N.Y.S.2d 333 (1973).

In Arringlon, the court stated: "This case presents much less than governmental advocacy. Rather, there is simply a governmental subsidy of a forum wherein others may express their views." $380 \mathrm{~F}$. Supp. at 1364.

142. See Canby, supra note 95 , at 1129-34.

[N]othing in the nature of an auditorium or school plant requires the exercise of editorial judgment over the entire facility; the auditorium and much of the school can function as well or better as a truly open forum. The advertising section of a school newspaper or a state university law review is also more effective when open and unrestricted, but the editorial, news, and articles columns of the periodicals are not. As long as alternative methods of expression are available, a right of access should be denied where the governmental enterprise cannot truly exist without the exercise of editorial discretion.

Id. at 1133-34.

143. There is the additional problem of self-perpetuation by an ideologically oriented group of students. A method of selection which facilitated this self-perpetuation would create a serious political establishment problem. On the other hand, an open process providing for an annual infusion of new personnel on a nonideological basis would be a solution. This is because the primary effect of funding the student media, as in the case of the municipal auditorium, would be unobjectionable. Admittedly, during the time when a particular group controlled the media there would be efforts to advance particular political views, but the relatively short duration of control would inean that the primary effect would be to create educational opportunities for students generally, and also to contribute to the overall dissemination of ideas within the institution.

144. While the maximum statutory period for a license is three years, 47 U.S.C. $\$ 307$ (d) (1976), it is recognized that the FCC renewal policies have made such a grant virtually perpetual. Central Florida Enterprises, Inc. v. FCC, 598 F.2d 37 (D.C. Cir.), cert. dismisscd, 99 S. Ct. 2189 (1979).

Despite the apparent statutory assurance of a free-wheehing inquiry into the relative merit of challenger and incumbent licensee, the history of Commission practice reveals a strong preference for renewal. Further, until fairly recently, such choices by the Commission were routinely affirmed by this court. This general phenomenon has been rationalized into what we have called on occasion 'a renewal expectancy.'

Id. at 42 (citatious omitted). 
ditionally, the CPB provides financial support for private noncommercial stations. The foregoing analysis suggests that political speech by private broadcasters enjoying one or both of these two benefits may constitute government dissemmation. As noted above, there is authority to the contrary. ${ }^{145}$ Furthermore, the monopolistic effects of indefinite tenure for broadcasters are diminished where, as in the case of radio, the large number of hicensees in a given community can provide a wide variety of pohtical views. Therefore, we may proceed on the premise that the FCC's licensing procedures and the CPB's funding activities constitute aid to private dissemination.

Where, however, indefinite hicensee tenure has a monopolistic effect due to the scarcity of competing hicensees, certain safeguards would be mandated to avoid a political establishment effect. To ensure that broadcasters present all sides of issues of public importance, Congress and the FCC have promulgated the regulatory framework described above, under which all stations are subject to the fairness doctrine and "equal time" requirements and private noncommercial stations are subject to additional requirements. ${ }^{146}$

This obviously raises entanglement questions. ${ }^{147}$ The political establishment analogue to the "government intrusion" aspect of entanglement forbids government aid that necessitates supervision unreasonably restrictive of free expression rights. The Supreme Court, however, has specifically held that the fairness doctrine does not unreasonably restrict the free speech rights of broadcasters. In Red Lion Broadcasting Co. v. FCC, ${ }^{148}$ the Court observed that the goal of balanced pohitical presentation in a public forum limited in size by the number of available channels requires the government to condition the receipt or retention of a license on the hicensee's fair treatment of issues

The development of Commission policy on comparative renewal hearings has now departed sufficiently from the established law, statutory and judicial precedent, that the Commission's handling of the facts of this case make embarrassingly clear that the FCC has practically erected a presumption of renewal . . . .

Id. at 51 .

The history of comparative renewal proceedings since 1 January 1961 . . discloses that mcumbents rarely have lost, and then only because they were disqualified on some noncomparative ground. From 1961 to 1978 the Commission has conducted seventeen comparative television license renewal proceedings, seven of which are still pending. In only two cases did the mcumbent lose its license, and in neither of those cases were the comparative criteria the grounds of decision.

Id. at 61 (citations omitted) (emphasis in original).

145. See text accompanying note 97 supra.

146. Kuczo v. Western Conn. Broadcasting Co., 566 F.2d 384, 388 (2d Cir. 1977).

147. The entanglement issue was not addressed $m$ the previous discussion of the restrictions placed on government stations because, as discussed in the text following note 69 supra, such concerns do not exist for direct governmental speecl.

148. 395 U.S. 367 (1969). 
of public importance. ${ }^{149}$ It found that this goal outweighed the free speech rights of broadcasters. ${ }^{150}$ This finding, although not specifically directed to the question of political establishment, obviously disposes of the question of excessive entanglement by the fairness doctrine.

Finally, the question remains whether the additional prohibitions against editorializimg and support or opposition for political candidates are constitutional when applied to private noncommercial stations receiving governmental aid. It appears that the fairness doctrine and "equal time" requirements are sufficient to eliminate any political establishment effect which might arise from such funding. Therefore, the additional restrictions are unnecessary for political establishment purposes and do not create true entangleinent problems. Rather, their constitutionality should be determined under the traditional free expression and/or equal protection analytic franework. ${ }^{151}$ The same would be true for the additional requirement that each program or series funded by $\mathrm{CPB}$ be strictly objective and balanced. No reported cases have considered these questions.

149. Id. at 375-79. The District of Columbia Circuit's original opinion in Florida Enterprises purported largely to do away with the unjustified renewal presuinption. $598 \mathrm{~F} .2 \mathrm{~d}$ at 51 . On petition for rehearing, however, the court issued a per curiam order of "clarification." Id. at 58. The Commission in its rehearing petition argued for the need to promote predictability and stability in the broadcasting industry. The court responded to this previously undeveloped rationale by suggesting that it appropriately be developed on remand or through a rulcmaking proceeding. Id. at 60. Apparently this "clarification" satisfied the Counmission's "agitated concern that [the] decision would destroy legitimate renewal expectancies," id. at 61 , and led to a voluntary dismissal of the petition for certiorari, 99 S. Ct. 2189 (1979).

150. 395 U.S. at $386-90$.

151. In Community-Service Broadcasting of Mid-Ainerica, Inc. v. FCC, 593 F.2d 1102, $1122-$ 23 (D.C. Cir. 1978) (en banc), the D.C. Circuit struck down on fifth annendment, due process/equal protection grounds subsections (a) and (b)(1) of $\S 399$ of the Public Broadcasting Act, 47 U.S.C. § 399(a)-(b)(1) (Supp. 1979). That section required noncomınercial licensees receiving assistance under the Act to tape all prograins that discuss any issue of public importance. Because first ainendinent rights were involved, the court evaluated the statute under a "stricter scrutiny" standard. It found that if the requirenent's objective was to preserve significant prograns or to enforce compliance with strict balance and objectivity standards, the language was substantially underinclusive; it should impose the taping burden on conmercial as well as noncommercial stations. 1f, on the other hand, the objective was to facilitate oversight of the expenditure of federal funds, the requirement applying to all progranning was unconstitutionally overbroad. $593 \mathrm{~F} .2 \mathrm{~d}$ at $1122-23$.

Most recently, in connection with a suit in federal district court, the Justice Department and the FCC informed Congress that they could not defend the antieditorializing provision of the Public Broadcasting Act against constitutional attacks. Attorney General Civiletti's reasoning paralleled that in Community-Service Broadcasting. The case was stayed to perinit Congress to determine whether it wanted to pursue a defense of the provision. BroadCASTINO, Nov. 18, 1979, at 79. See Lindsey, Public Broadcasting: Editorial Restraints and the First Amendment, 28 FED. Сом. В.J. 63, 76-98 (1975). 


\section{Public Financing of Political Campaigns}

In Buckley v. Valeo, ${ }^{152}$ the Court summarily disposed of a first amendment attack on public financing of political campaigns. Petitioner's coinpelled adherence argument certainly warranted such treatment. As the Court poimted out, "the scheme involves no compulsion upon mdividuals to finance the disseınination of ideas with which they disagree . . . . The $\S 6096$ check-off is simply the means by which Congress determines the amount of its appropriation." 153 The Court failed, however, to adequately evaluate petitioner's religious establishment analogy. Concededly, the purpose of the campaign financing prograin - to eliminate the improper influence of large private contributors and to facilitate and increase public participation $\mathrm{m}$ the electoral process-is legitimate, but substantial primary effect and entanglement probleuns may exist.

Entanglement was the only aspect of political establishment that the Court explicitly addressed under its first amendment analysis. A footnote rejected as "wholly speculative" the contention that public financing would result in government intrusion into the "internal affairs of political parties and a consequent loss of political freedoin." 154 Focusmg in part on the entanglennent danger, Chief Justice Burger dissented from the public financing portion of the Court's opinion. $\mathrm{He}$ noted that the Act "specifically requires the auditing of records of political parties and candidates by government inspectors," and chastised the Court for showing "little sensitivity to the danger it has so strongly condemned in other contexts." 155

The Court's response to the Chief Justice's entanglement concerns was inadequate. Nevertheless, the entanglement at issue in this case was not excessive. It consisted only of financial auditing of the recipient political parties' financial records; it was not content-oriented, and consequently did not raise tlie kind of danger that the Court designed the entanglement test to prevent. ${ }^{156}$

The Court addressed the discriminatory political effects of public financing only in a fifth amendment, due process-equal protection context. It reasoned first that the public financing plan generally does less to restrict access to the electoral process than did the ballot access regu-

152. 424 U.S. 1 (1976).

153. Id. at 91 n. 124 .

154. Id. at 93 n. 126 .

155. Id. at 249-50 (Burger, C.J., dissenting). See also id. at 291 (Rehnquist, J., dissenting).

156. See text accompanying notes 58-61 supra. Chief Justice Burger appeared to be concerned with possible future risks of content control arising out of general government surveillance, rather than with problems specifically raised by any of the statutory auditing provisions designed to enforce spending ceihings. 424 U.S. at 249-50 (Burger, C.J., dissenting). 
lations it reviewed in prior cases. ${ }^{157}$ The Court then stated that there was no showing that the plan decreased the strength of minority parties in absolute monetary terms below that attained without any public financing. These parties remained free to raise private money and spend as inuch as they chose. Also, to the extent that minority parties qualified for partial public funding, they still could spend up to the generally applicable limit. ${ }^{158}$ The Court next found that any detriment inflicted by the plan's eligibility formula "was limited to the claimed denial of the enhancement of opportunity to communicate with the electorate that the formulae afford eligible candidates." 159 Finally, it decided that minority parties are not put at a comparative disadvantage by their ineligibility for funding because the program requires eligible parties to accept as a quid pro quo for pubhic financing an otherwise inapplicable expenditure limit. ${ }^{160}$ From these observations the Court concluded that the provisions for minority parties did not unfairly or unnecessarily burden the political opportunity of any party or candidate. ${ }^{161}$

The Court failed to consider, however, that a political campaign is a battle of ideas as well as of candidates and political parties. The two major political parties generally adopt conventional ideas that accept the social and econonnc status quo with only relatively small differences in emphasis. In contrast, mmor parties often advance unconventional ideas. ${ }^{162}$ Dissemmation of such unpopular views is important to

157. 424 U.S. at 95.

158. Id. at 99 .

159. Id. at 95 .

160. Id.

161. However, the Court did state in a footnote that it was dealing only with the financing plan's facial vahitity. Thus it "did not . . . rule out the possibihity of concluding in some future case, upon an appropriate factual demonstration, that the public financing system imvidiously discriminates against nonmajor parties." Id. at 99.

It is arguable that the Court should have applied a strict scrutiny-compelling state interest test. Admittedly, in recent racial discrinmation cases the Court has been unwilling to apply strict scrutiny to facially nonsuspect classifications regardless of the adverse impact such classifications may have. E.g., Arlington Heights v. Metropohtan Hous. Corp., 429 U.S. 252 (1977); Washington v. Davis, 426 U.S. 229 (1976). In Tinker v. Des Moines School Dist., 393 U.S. 503 (1969), however, the Court stated that conduct "closely akin to speech" may be treated as speech. Id. at 50506. By analogy, the classification between inajor and minor parties may be so close to one based on content that no differentiation should be allowed if it does not serve a compelling state interest. Even if the distinction in Buckley is found to serve such an interest, it inight be invalidated because other, pohtically nondiscriminatory means exist. $C f$. Buckley v. Valeo, 424 U.S. 1, 245 (Burger, C.J., dissenting).

If, however, the Court was correct in refusing to apply strict scrutiny, the remainder of its analysis is sound. It stated that the major-minor party distinction furthered two goals: (1) not funding hopeless candidates with large sums of public nnoney; and (2) not providing artificial incentives to "splintered parties and unrestrained factionalism." Id. at 97. Thus, the distinction inade it practical to use public financing to further legitimate governmental interests.

162. See Illinois St. Bd. of Elec. v. Socialist Workers Party, 440 U.S. 173, 185-86 (1979); 424 
a democratic political process. Its importance is illustrated by the historical fact that the major parties have adopted many previously unconventional ideas and turned them into law. ${ }^{163}$

The present public financing system has the effect of allocating far more federal money for the propagation of conventional majority ideas than unconventional minority ideas. The Court's argument that the plan at least does not impair the ability of minority parties to raise funds misses the point. ${ }^{164}$ Public financing is clearly a scarce resource that can have a major impact on the political process. Unequal distribution of this resource by the government may distort the marketplace of ideas and thus raises serious political establishment concerns.

Under a political establishment framework, the Court would have invalidated the campaign financing plan in Buckley. The plan's primary effect - the advancement of majority political views over mmority views-is clearly impermissible. The political establishment clause would permit a public financing plan only if it provided equal government aid for all political parties. As a practical matter, such a requirement might make public financing of campaigns infeasible.

\section{Public Financing of Legal Services for The Poor}

Except in criminal cases ${ }^{165}$ and perhaps in some civil matters where the individual also confronts the power of the state, ${ }^{166}$ there is no recognized constitutional obligation to provide an indigent with legal assistance. ${ }^{167}$ The Legal Services Corporation Act of $1974^{168}$ goes beyond what is constitutionally mandated, however, in order to "provide high quality legal assistance to those who otherwise would be unable to

U.S. at 70; C. Merriam \& H. Gosnell, The American Party System 59-62 (1949) [hereinafter cited as MERRIAM \& GOSNELL]; Herring, The Significance of Third Party Activities, in THE AMERICAN PARTY System 93, 94 (J. Owens ed. 1968); Levi, Toward Functionalism in Political Science: The Case of Innovation in Party Systems, in American Political Parties, A Systematic PerSPECTIVE 452, 474-75 (C. Mayo \& B. Crowe eds. 1967).

163. See 424 U.S. at 101-02; MERRIAM \& GosNeLl, supra note 162; Herring, supra note 162; Levi, supra note 162. See also I. Hinderaker, Party Politics 75 (1956).

164. Moreover, this analysis demonstrates that the ballot access decisions on which the Court relied heavily are inapposite. It is true that the public campaign financing program requirement that a political party must have some minimal degree of public support before it is eligible for aid is similar to most ballot access rules. See, e.g., Jeness v. Fortson, 403 U.S. 431 (1971); Williams v. Rhodes, 393 U.S. 23 (1968). This requirement, however, has a greater effect in the financing context. Campaign funding, unlike ballot access, correlates closely with the ability to gain public support in the first place; without some aid at the outset, many minority parties may never be able to marshall enough such support to qualify under the plan. Thus, contrary to the Court's finding, the financing of election campaigns involved in Buckley perpetuates the political status quo even more than do ballot access restrictions.

165. Argersinger v. Hamlin, 407 U.S. 25 (1972).

166. Houseman, Equal Protection and the Poor, 30 Rutgers L. Rev. 887, 888-90 (1977).

167. See Cramton, Promise and Reality In Legal Services, 61 CoRnell L. Rev. 670, 675

(1976); Ventantonio, Equal Justice Under the Law, 7 SETON HALl L. Rev. 233, 252-60 (1976).

168. 42 U.S.C. $\$ 2996$ (1976). 
afford adequate legal counsel."169 Few would question the legitimacy of "legal aid" activities that provide assistance to an indigent seeking a divorce, being sued on a lease or installment contract, or receiving inadequate services froin his or her landlord. The principal element of constitutional doubt about publicly funded legal services is their "law reform" component - efforts to effect fundamental changes in the legal system through litigation or other means. ${ }^{170}$

Applying the tripartite analytic framework froin Lemon, if the purpose and/or primary effect of a legal services program's litigation activities is to espouse reform objectives independently formulated by the program-expression that the free speech clause would protect if privately financed ${ }^{171}$ - the political establishment clause would prohibit those activities. Further, if those activities involve excessive entanglement with the free expression rights of individuals or private groups, they are similarly unconstitutional.

The Supreme Court has held that law reform litigation can be a type of protected first amendment activity. ${ }^{172}$ Most recently, in In re Primus, ${ }^{173}$ the Court ruled that a state could not apply its antisolicitation rules to a case brought by a volunteer ACLU lawyer. In this setting, " "litigation [was] not a technique of resolving private differences"; it [was] 'a form of political expression' and 'political association.' "174

169. Id. $\$ 2996(2)$.

170. See E. Johnson, Justice AND REForm 278-84 (1974); Sullivan, Law Reform and the Legal Services Crisis, 59 CAL1F. L. Rev. 1, 24-28 (1971). Compare Agnew, What's Wrong with the Legal Services Program, 58 A.B.A.J. 930 (1972), with Klaus, Legal Services Program: A Reply 10 Vice President Agnew, 58 A.B.A.J. 1178 (1972).

Representatives Ashbrook and Huber, dissenting from the House Committee report on the Legal Services Corporation bill, observed:

[The ordinary citizen's] taxes would go to activist, social reforming attorneys who would be free to file suits supposedly on behalf of poor clients that the taxpayer himself would have neither the time nor the money to conduct. Often his town or county will also have to hire a lawyer-again out of his taxes-to defend the suit. Or if he is a small businessman, perhaps he cannot afford to defend a suit brought with his own tax inoney against hiin.

[1974] U.S. Code Cong. \& AD. News 3894.

171. Like the Corporation for Public Broadcasting, the Legal Services Corporation is established as a federally chartered private nonprofit corporation. 42 U.S.C. $\$ 2996 \mathrm{~b}$ (a) (1976). The Legal Services Corporation serves as a funding inechanism for a multitude of separately incorporated "legal services programs" across the country. Certain aspects of legal services programs' activities have been held not to constitute state action, despite such programs' receipt of substantial government funds. See, e.g., Lefcourt v. Legal Aid Soc'y, 445 F.2d 1150 (2d Cir. 1971) (discharge of attorney by Legal Aid Society of the City of New York was not state action). In cases involving alleged violations of clients' constitutional rights, however, the argument for finding state action wonld be stronger. See McCoy, Current State Action Thcories: The Jackson Nexus Requirement \& Employee Discharges by Semi-Public and State-Aided Institutions, 31 VAND. L. REv. 785 (1978).

172. NAACP v. Button, 371 U.S. 415, 429-30 (1963). See also Maryland Pub. Interest Group v. Elkins, S65 F.2d 864, 866 (4th Cir. 1977), cert. denied, 435 U.S. 1008 (1978).

173. 436 U.S. 412 (1978).

174. Id. at 428 (quoting NAACP v. Button, 371 U.S. 415, 429, 431 (1963)). Cf. Ohralik v. Ohio State Bar Ass'n, 436 U.S. 447 (1978) (upholding the validity of antisolicitation rules as ap- 
The Court in Primus described the ACLU as an organization which "represented individuals in litigation that has defined the scope of constitutional protection in such areas as political dissent, juvenile riglits, prisoners' rights, military law, amnesty and privacy."175 More specifically, the ACLU's purpose in pursuing such hitigation was the achievement of certain pohtical objectives rather than client representation for its own sake. ${ }^{176}$ A footnote in Primus stated that "there is nothing in the record to suggest that the ACLU . . . is an organization dedicated exclusively to the provision of legal services."177 The implication is that the litigation activities of an organization dedicated to the provision of legal services would, in contrast to those of the ACLU, not involve the exercise of first amendment rights.

The legislatively stated objective of legal services programs is simply to provide representation. Indeed, the Legal Services Corporation legislation contains several provisions designed to meet objections to what some viewed as past abuses in the program. ${ }^{178}$ None of these provisions preclude law reform activities, however, as long as those activities are arguably part of the representation of a client. Further, because legal services programs have only limited resources, like the ACLU, they probably accept cases on the basis of the amount of reform impact the cases might have on legal treatment of the poor as a class. Thus, to soine degree, in the cases brought by both legal services and the ACLU the individual client may become an incidental vehicle for attaining desired policy results. This is a clearly impermissible purpose and primary effect for a government-funded organization.

Finally, entanglement problems may arise here. Indigent clients who bring suits to achieve social reform engage in speech protected by the first amendment. But where legal services attorneys either persuade chents to undertake such hitigation, or, on the other hand, downplay the reform aspects of the suit to avoid primary effect problems, there is excessive government entanglement.

\section{Favorable Tax Treatment}

In Walz v. Tax Commission, ${ }^{179}$ the Supreme Court upheld the con-

plied to personal solicitation of accident victims for purposes of representing them on contingent fee basis: "A lawyer's procurement of remunerative employment is a subject only marginally affected with First Ainendment concerns." 436 U.S. at 459).

175. 436 U.S. at 428.

176. Id. at 427 .

177. Id. at 428 n. 20 (emphasis added).

178. See George, Development of the Legal Services Corporation, 61 Cornell L. Rev. 681, 705-09 (1976). In 1977, the Legal Services Corporation Act Amendments were enacted. Pub. L. No. 95-222, 91 Stat. 1619 (1977).

179. 397 U.S. 664 (1970). 
stitutionality of state property tax exemptions for religious organizations. The District of Columbia Circuit relied on Walz in Marker $\nu$. Schult $z^{180}$ to sustain the tax exempt status of labor unions ${ }^{181}$ despite their involvenent in partisan pohtical activity:

As Walz holds, a tax exemption with a neutral stance, not rooted in a purpose to give aid, does not constitute an establishment of rehigion, which is expressly forbidden by the Establishment Clause . . . . It does not constitute the kind of estabhishment of pohtical support that is impliedly prohibited by the First Amendment. ${ }^{182}$

The court stated that Congress did not base the tax exemption on support of each aspect of union activity but "on the concept that what was involved was essentially a pooling of the individual resources of the members as contrasted with entrepreneurial profit of corporations." 183 Moreover, the absence of any limitation on political activity as a condition for retaining tax-exempt treatment rested on a congressional deterinination not "to enibroil the tax laws and the agencies admimistering them into involveinent with and surveillance of the political activities of the union." 184

Walz' purpose-effect-entanglement analysis is instructive of how to treat the political establishment problem posed in Marker. ${ }^{185}$ That analysis upheld a tax exemption for cliurclies. It is therefore difficult to envision how the Marker court could have struck down the exemption for labor unions on purpose or entanglement grounds. The tax exemp-

180. 485 F.2d 1003 (D.C. Cir, 1973).

181. I.R.C. $\$ 501(\mathrm{c})(5)$.

182. 485 F.2d at 1006 .

183. Id. at 1007 .

184. Id.

185. It may be argued that in reaching its conclusion the Court did not apply the tripartite test which it was to articulate more fully a year later in Lemon v. Kurtzman, 403 U.S. 602 (1971). The Court found the purpose of the exemption to be acceptable and found no excessive entanglement by distinguishing the exemption in which "the government . . . simply abstains from demanding that the church support the state," from a direct subsidy which would be "pregnant with involvement." 397 U.S. at 674-75.

But this treatment ignored the most difficult of the three questions posed in Lemon: whether the exemption's primary effect was to advance religion. The Court acknowledged that the tax exemption does provide an "indirect" economic benefit, but this acknowledgment occurred only by way of emphasizing that the exemption produced less entanglement than would arise from taximg the churches. Id. It would have been most difficult to avoid finding an unacceptable primary effect if analysis of this issue had proceeded along the lines of the later parochial school aid decisions.

The Court then focused at some length on tle long history of favorable tax treatment accorded religious organizations. $I d$. at 675 . In addition to property tax exemptions dating back to colonial times, the Court referred to the Internal Revenue Code. It cited provisions by which religious, as well as other social welfare organizations, long have been exempted from federal taxation. Id. at 676. Given the prior deficiencies and lack of clarity in the Court's purpose-effectentanglement analysis, it may be suggested that the Court actually was creating an historical exception to the coverage of the establisliment clause. Id. at 1007. If this is the case, the decision in Walz is largely irrelevant to Marker. 
tion would constitute a political establishment only if it had the primary effect of advancing an identifiable union perspective over conflicting political views.

There is no basis for concluding in Marker that the tax exemption given to unions constitutes a subsidy to only one side of various political issues. ${ }^{186}$ First, on any given issue, particularly outside the inajor economic ones, all unions may not take the same position. Second, the principal opposition to union political positions is hkely to come from business firms that enjoy offsetting tax advantages througl deductibility of lobbying expenses. ${ }^{187}$

The possibility that the various exemptions and deductions in the Internal Revenue Code might have an indirect "de facto" discriminatory effect among participants in a political debate arose more clearly in Haswell $v$. United States. ${ }^{188}$ Haswell had made contributions to the National Association of Railroad Passengers (NARP), an organization formed to lobby the legislature to preserve and improve passenger rail service. The Internal Revenue Service had denied Haswell a charitable deduction for his contributions on the grounds that NARP engaged in political activities and lience failed to meet the requirement of section 170(c)(2)(D) of the Code.

Haswell argued that the IRS's position was unconstitutionally discriminatory because "contributors to NARP would be denied a tax deduction for lobbying on the same legislation and issues that businesses are perimitted to lobby against and to deduct under Section 162(e) . . . the costs of sucli lobbying as ordinary and necessary business expenses." 189 The court responded that

such division has long been recognized and is reasonable. Congress has recognized the propriety of a deduction as an ordinary and necessary expense for business with respect to legislation . . . that directly affects the ability of business to produce income and to pay taxes thereon. The deduction is related to the profit-motivated activities of the taxpayer. Activities of charitable organizations stein from different motivations, and contributions to such organizations are matters of personal concern. Absence of a standard generally applicable justifies differentiation in a separate class. ${ }^{190}$

186. This disposes of any argument based on Police Dep't v. Mosley, 408 U.S. 92 (1972), that the granting of tax-exempt status to labor unions is a content-oriented distimction like the exemption of unions from the ban on picketing near public schools. See notes 133-34 and accompanymg text supra. See also Taxation With Representation v. United States, 585 F.2d 1219, 1225 (4th Cir. 1978) (Winter, J., concurring and dissenting), cert. denied, 99 S. Ct. 1994 (1979).

187. I.R.C. \& 162(e).

188. 500 F.2d I133 (Ct. Cl. 1974), cert. denied, 419 U.S. 1107 (1975).

189. I.R.C. $\& 501(\mathrm{c})(3)$.

190. $500 \mathrm{~F} .2 \mathrm{~d}$ at 1150 . It is interesting that the Haswell concurring opinion seriously questioned the differential tax treatment of lobbying and hitigation: 
The court's response suggests that no improper political purpose exists in this case. It stresses the underlying tax policy reasons for differentiating a business' income-producing expenses from payments made to promote the activities of a nonprofit organization such as NARP. Certainly those reasons are unrelated to the possible content of expression by the business and nonbusiness entities.

Haswell would argue, however, that under political establishment principles the primary effect of the distinction was to subsidize only the railroads' position in their sharp political controversy with NARP. The possible existence of this effect, as in the political cainpaign financing and legal services cases, requires closer examination.

There is no necessary correlation between firms that deduct lobbying expenses and any particular political position. Certainly most, if not all, railroads opposed continuation of passenger service. Within the broader class of busmess firms, however, it is unlikely that all would take the saine lobbying stance on proposed legislation affecting railroads. Trucking firms, for example, might well have supported NARP's pro-rail passenger service stance. Also, organizations that enjoy tax exempt status, such as labor unions and civic leagues, similarly might have sided with NARP. Thus, there was no showing in Haswell of any substantial tax relief support for certain political views sufficient to warrant a finding of political establishment.

There inay be a more serious establishment problem in the tax exeinption given to organizations largely devoted to litigation, such as legal services programs. Legal representation for "a disadvantaged ininority, the victims of racial discrimination, or those denied human and civil rights either in criminal or civil matters . . . has long been recognized as a [section 501(c)(3)] charitable activity . . . . ${ }^{191}$ Moreover, in recent years Congress has accorded tax-exempt treatment to "public interest" law firms, which provide representation "either in soine specific area of public concern, such as protection of the environinent, or more broadly upon any subject of public interest." 192

Because the political establishment clause would probably prohibit

An organization like NARP has a choice of seeking its ends by advocating or opposing legislation in Congress or by 'public interest' litigation. . . . NARP did both. The former is the most direct possible form of petitioning for redress of grievances under Amendment I of the Constitution. To hold that an organization that has qualified under [subsection] (B) loses its status because it petitions even though in the most correct and lawful fashion, but not if it litigates, however unethically, or foments litigation, is to create a discrimination that raises constitutional difficulties for une that neither the trial judge nor the autliorities he cites wholly resolve.

Id. at 1150-51 (Nichols, J., concurring).

191. Rev. Proc. 71-39, 1971-2 C.B. 575, 5 Fed. TAX RPTR. (CCH) q3033.4537 (1979). See Rev. Rul. 69-161, 1969-1 C.B. 149.

192. Id. See generally Center on Corporate Responsibility, Inc. v. Shultz, 368 F. Supp. 863 (D.D.C. 1973). 
direct government subsidies for law reform activities, ${ }^{193}$ the tax exemption for those activities is also questionable. There is a difference, however, between the tax exemption and the direct subsidy through the Legal Services Corporation. The subsidy is available only to a select group of legal services programs whereas the exemption appears to be more broadly available. If the exemption's availability is unrelated to the various organizations' policy objectives, there would be no political establishment difficulty. ${ }^{194}$

The tax-exempt status of public interest law firms appears to depend on two factors: (1) the firm must advocate legal positions on issues that liave broad public impact; and (2) these positions normally would not be submitted to the courts because of the cost of litigation. More specifically, under the second factor there should be no financially able potential chents in whose interests a lawyer could offer such positions on a normal fee-generatimg basis. ${ }^{195}$ These IRS standards are extremely general. As a result, it is even more difficult to discern a political establishment problem here than in the case of other charitable groups rendering legal representation.

\section{CONCLUSION}

The imphed political establishment clause would prohibit government advocacy of political viewpoints and unequal government assistance to private pohtical dissemination. It is a logical elaboration of first amendment values that promote fair play in the decisionmaking processes vital to deinocratic government.

As with any broad concept, the problems of application are difficult and require subtle judgments. Decisions under the analogous religious estabhishment clause verify such difficulty. This Article has deinonstrated, however, that courts can draw upon many sources to develop a workable standard of pohtical estabhishment.

This Article does not suggest that government advocacy of political viewpoints presently poses a serious threat to democratic processes in this country. The prohibition against pohtical estabhshment would, however, require the elimination or alteration of many existimg government practices. Moreover, it stands along with other first amendment rights as an ultimate safeguard of political freedoms.

193. See text accompanying notes $165-78$ supra.

194. This would be the case, for example, with reference to tax-exempt status for private schools and for radio or television stations operated by charitable foundations.

195. Rev. Rul. 75-74, 1975-1 C.B. 152. 